\title{
Environmental Damage Insurance in Theory and Practice
}

Citation for published version (APA):

Faure, M. G. (2002). Environmental Damage Insurance in Theory and Practice. In Swanson T. (Ed.), An Introduction to the Law and Economics of Environmental Policy: Issues in Institutional Design (pp. 283328). JAl. https://doi.org/10.1016/s0193-5895(02)20015-9

Document status and date:

Published: 01/01/2002

DOI:

10.1016/s0193-5895(02)20015-9

Document Version:

Publisher's PDF, also known as Version of record

\section{Please check the document version of this publication:}

- A submitted manuscript is the version of the article upon submission and before peer-review. There can be important differences between the submitted version and the official published version of record.

People interested in the research are advised to contact the author for the final version of the publication, or visit the DOI to the publisher's website.

- The final author version and the galley proof are versions of the publication after peer review.

- The final published version features the final layout of the paper including the volume, issue and page numbers.

Link to publication

\footnotetext{
General rights rights.

- You may freely distribute the URL identifying the publication in the public portal. please follow below link for the End User Agreement:

www.umlib.nl/taverne-license

Take down policy

If you believe that this document breaches copyright please contact us at:

repository@maastrichtuniversity.nl

providing details and we will investigate your claim.
}

Copyright and moral rights for the publications made accessible in the public portal are retained by the authors and/or other copyright owners and it is a condition of accessing publications that users recognise and abide by the legal requirements associated with these

- Users may download and print one copy of any publication from the public portal for the purpose of private study or research.

- You may not further distribute the material or use it for any profit-making activity or commercial gain

If the publication is distributed under the terms of Article $25 \mathrm{fa}$ of the Dutch Copyright Act, indicated by the "Taverne" license above, 


\title{
ENVIRONMENTAL DAMAGE INSURANCE IN THEORY AND PRACTICE
}

\author{
Michael Faure
}

\begin{abstract}
In this paper, some particularities of envirommental insurance are addressed. First, the paper summarizes the general conditions of insurability. Then, it is explained why insuring environmental liability may be difficult. Specifically, the necessity of an adequate risk differentiation may be difficult to obtain in cases of environmental liability. Then, it is explained how, at the theoretical level, a move lowards different insurance schemes (notably first party or direct insurance schemes) provides a solution to problems of insurance of envirommental liability. Although the move towards first party or direct environmental insurance way seem attractive at a theoretical level, nevertheless a variety of practical questions may arise. The alternative utilized in practice is not first panty insurance (whereby victims would lake out insurance coverage), but a form of direct insurance, whereby envirommental damage is insured directly, that is to say as soon as damage occurs and irrespective of liability. The paper then discusses a recent example of such a direct enviromental insurance, as it was applied in the Netherlands. Alhough this system seems to have considerable benefits, the major disadwantage lies in the fact that apparenily all insurers in the Netherlands moved to this new environmental
\end{abstract}

\footnotetext{
An. Introduction to the Law and Economics of Emwironmentall Policy: Issues in Instifutional Design, Volume 20, pages 283-328.

Copyrigh 02002 by Elsevier Science Ltd.

All rights of reprodaction in any form reserved.

ISBN: 0-7623-0888-5
} 
damage insurance. This raises important questions as to the competitiveness of the particular narket.

\section{INTRODUCTION}

Many have pointed at the fact that the scope of liability of industrial operators is increasing in Europe as well." This expanding liability also seems to hit the area of environmental liability and, in combination with an increasing tendency towards intensified (command and control) regulation, some have argued that the polluter pays double. A recent white paper on environmental liability, launched on 9 February 2000 by the European Commission, seems - to some extent - to confirm this tendency: the white paper proposes a strict (although non-retroactive) environmental liability for damage caused to biodiversity, provided that it is caused by dangerous and potentially dangerous activities, regulated by EC environment related law. ${ }^{3}$

One result of the seemingly expanding scope of environmental liability is that - not surprisingly - this has led to great concern for the European liability insurers. An often-heard reaction, with many changes in liability law, is that as a result of these expansions, the environmental liability would beconke uninsurable. Whether this expanding environmental liability indeed endangers the insurability of the liability risk is not the topic I am going to examine in this paper.* An interesting effect of these changes in liability law is, however, that both insurers and industrial operators seem to be looking for alternatives to liability insurance to cover environmental risks. Several alternatives have been developed, going from the use of capital markets to the installation of compensation funds. ${ }^{5}$

There is one particular alternative, which merits a closer look. It concerns more particularly the tendency in some countries to move away from third party liability insurance towards first party insurance. It is precisely this tendency that I would like to examine more closely in this paper. The reason is that this change from third party towards first party insurance seems at first blush to correspond nicely with George Priest's suggestion that this would be an appropriate remedy for the American insurance crisis. ${ }^{6}$ Some insurers seem to have taken Priest's wamings for a liability crisis seriously and the same is apparently true for the remedies he proposed. One can, especially in the envirommental sphere, notice an increasing tendency towards first party insurance. This is, by the way, not only the case in the environmental area, but also, e.g. in occupational health and medical malpractice and an increasing use of first party insurance is even also discussed in the traffic accident area. Therefore, this phenomenon definitely merits a closer look. 
In this paper I will first of all look at the theoretical differences between first party and third party insurance. The question arises how, at least in theory, the two differ as far as their ability to prevent environmental harm is concerned as well as the possibility to provide adequate compensation to accident victims (Section 2). Then we will take a practical example provided by the Netherlands since the Dutch insurers recently decided to more or less abolish environmental liability insurance and change radically towards environmental damage insurance. We will have a critical look at this policy and examine whether this is indeed an acceptable example, which should be followed by other countries (Section 3). Obviously at the policy level, several questions arise, which are important both for the liability and for the first party insurance area. These policy issues have to do with the question whether insurance coverage should be made compulsory and also relate to the importance of competition policy to guarantee fully competitive insurance markets (Section 4). All of these issues will be addressed using the economic analysis of tort and insurance. The reason for using the law and economics method is obvious: it provides the adequate tools to examine critically whether various insurance devices can lead to optimal prevention and compensation.

A few concluding remarks concludes the paper (Section 5).

\section{FIRST PARTY VS. THIRD PARTY INSURANCE: THEORETICAL DIFEERENCES}

\section{Introduction}

In the economics of accident law and insurance the reasons why persons seek insurance coverage have been explained. The utilitarian approach with respect to insurance has demonstrated that risk creates a disutility for people with risk aversion. Their utility can be increased in case of loss spreading or if the small probability of a large loss is taken away from the injurer in exchange for the certainty of a small loss. The latter is of course, exactly the phenomenon of insurance. The risk averse injurer has a demand for insurance; he prefers the certainty of a small loss (the payment of the insurance premium) whereby the probability of a larger loss is shifted to the insurance company, thereby increasing the utility of the injurer. ${ }^{8}$ It is remarkable that in this utilitarian approach of insurance, liability insurance is in the first place regarded as a means to increase the utility of a risk averse injurer, not so much as a means to protect victims, as is sometimes argued by lawyers.

The reason an insurance company can take over the risk of the injurer is well known: because of the large number of participants the risk can be spread 
over a larger group of people. The insurer only has to pay attention that he builds relatively small risk groups in which the premium is as much as possible alligned to the risk of the members of that group.

In addition to this utility-based theory of insurance which sees insurance as an instrument to increase the expected utility of risk averse persons through a system of risk spreading, Skogh has powerfully argued that insurance may also be used as a device to reduce transactions costs."

Thus, one can easily apply these general principles to explain why there will be a demand for environmental liability insurance: it can provide protection for risk awerse injurers. However, it has been argued that several conditions have to be met to keep (environmental) liability an insurable risk. Let us look briefly: at these conditions of insurability of liability. The question we are interested in within the scope of this paper is obviously whether some of these conditions of insurability might be easier to meet in case of fist party than in case of third party insurance.

\section{Insurability of Environmental Liability: A Brief Overview}

Let us look at those conditions which are generally listed in the literature, either positively as conditions which have to be met to guarantee the insurability of (environmental) liability or, formulated negatively, as factors which may endanger the insurability of (environmental) liability: ${ }^{10}$

\section{Predictability, Uncertainty and "Inswrer Ambiguity"}

Obviously for every insurance scheme, also for envirommental liability insurance, it is crucial that the insurer possesses accurate intormation on the likelihood that the event will occur (the probability) and on the possible magnitude of the damage once the accident will occur. These expectations on probability and magnitude of the loss are essential for the insurer to be able to calculate his somcalled actuarially fair premium. Increased with the so-called loading costs (for among others administrative expenses) and, depending on the market structure, a profit margin, this will constitute the premium to be paid by the insured.

In this respect environmental liability insurance is obviously not different than any other type of insurance; for these general principles we can hence refer to the insurance economics literature. However, it is important to stress that one crucial element in insurance, already to make an accurate premium calculation possible, as we just indicated, is precise information on the probabillity that a certain loss will occur and the possibility to make a more or less accurate estimate of the potential magnitude of the damage. This is not 
only necessary in order to make an accurate estimation of the premium to be charged, but also to set aside a reserve in case the accident for which insurance coverage was seeked occurs.

If the insurer ideally has ex ante perfect information on the predictability of the probability and the magnitude of the damage, we call the particular risk insurable. It is precisely on the basis of statistics that the insurer will require information on the likelihood that the risk will occur with a particular insured; statistics may also provide information on the possible magnitude of the damage. Both these requirements may, however, be a problem in the case of environmental (liability) insurance. Several elements may negatively influence the ex ante predictability of the risk. "The ex ante information on the predictability of the risk is often low, given the relatively new character of environmental risks. Reliable statistics may sometimes be missing both with respect to the probability of the event occurring and with respect to the damage. ${ }^{12}$ Hence, there may not be a "law of large numbers" to be applied. This obviously is not only a problem for environmental insurance, but occurs in every case where insurers are confronted with new risks, where reliable data may be missing.

The question therefore arises whether the predictability of the liability risk can be increased, even in the absence of reliable statistics, or whether in that case the particular risk should be judged as uninsurable. The literature has indicated that uncertainty concerning the probability or the damage is of course an element with which the insurer can, in principle, take account ex ante. If there is uncertainty, because of a lack of reliable statistics, this should not necessarily lead to the conclusion that a particular risk is uninsurable. We are then dealing with the concept referred to as "insurer ambiguity" addressed by Kunreuther, Hogarth and Meszaros. ${ }^{13}$ They argue that the insurer can react to this uncertainty concerning either the probability of the event or the magnitude of the damage by charging a so-called risk premium to account for this unpredictability. Hence, an insurer can, in principle, also deal with a "hard to predici" event, by charging an additional premium.

\section{Capacity}

We have already mentioned that a requirement for insurability is that the insurer should have ex ante information on the predictability of the risk and on the magnitude of the damage. So far we have dealt with the importance of the predictability of liability. However, also the magnitude of the harm may constitute a problem.

There may be uncertainty as far as the possible magnitude of the harm is concerned. The insurer may react to this uncertainty by providing for an adequate reserve to be able to provide coverage for the environmental damage 
once it occurs. However, in many cases the expected loss may exceed the possibilities of the individual insurer. In that case the insurer can use various traditional insurance techniques to cope with this capacity problem. One possibility is to insure a similar risk jointly with a few insurers (so-called co-insurance); another possibility is re-insurance. One other solution, which is often used in cases of environmental liability insurance, is pooling of capacity by insurers. In many countries insurers have shared risks in mutual pools on a non-competitive basis to be able to provide coverage, also for risks with a relatively high potential magnitude. This is typically the case for the nuclear risk.

\section{Moral Hazard}

If risk is fully removed from the injurer and shifted to the insurer, the injurer will indeed miss the incentive for care taking that was exactly given to him by the deterrent effect of having to pay compensation in case of an accident. Marc Pauly has, by the way, indicated that in fact this behaviour of the injurer is not immoral but completely rational since he simply reacts to varying costs for his behaviour. ${ }^{14}$ For the insurer of course the problem arises how nevertheless incentives can be given to the insured to behave in exactly the same way as if no insurance were available. This is, of course, the goal of an optimal control of moral hazard. 15

In the literature two ways of controlling the moral hazard problem are indicated. ${ }^{16}$ The first is a control of the insured and an appropriate adaptation of the premium; the second is exposing the insured partially to risk. A first best solution is a detailed control of the insured." In that case the premium conditions would be exactly adapted to the behaviour of the insured and the premium would reffect the care taken by the insured. In an optimal world this should give the insured incentives to behave exactly as if no insurance were available and the premium would reflect the true accident risk. Of course, this first best solution is only possible in the ideal world where control by the insurance company would be costless and information on the behaviour of the insured readily available. In practice this is of course not the case. There are, however, some means for a control of the insured and a differentiation of premium conditions according to certain groups of risk. This can either be an ex ante screening with a higher premium for certain high risk groups or an ex post premium increase or change of policy conditions based on previous loss experience. This is the so-called experience rating. Much of insurance legislation is also aimed at reducing moral hazard. ${ }^{18}$ Think in this respect, e.g. of the prohibition, contained in many insurance laws, to insure accidents which are caused with intent. 19 
A second best solution is exposing the insured partially to risk. This is considered second best because insurance should ideally exactly aim at removing risk from the injurer. Exposing the insured to risk will mean that some degree of risk aversion will remain. This has, on the other hand, the advantage that the insured injurer will still have some incentives for care taking although he is insured. This exposure to risk can be either at the lower level of damage or at the higher level. One could indeed think of a system with a deductible whereby a lower threshold applies or one could introduce an upper limit on coverage whereby the insured bears his own loss in case the damage exceeds the insured amount.

\section{Adverse Selection}

As indicated above, that the insurance is based on a system of loss spreading. Therefore the insurer needs a minimum number of similar risks he insures. At the same time risk pools have to be constructed as narrow as possible, meaning that the average premium in the risk pool should correspond with the risk of most of the members in the particular pool. Would this not be the case, then the average premium would be relatively high for low risk members, which would then leave the group. In that case the well-known phenomenon of adverse selection could emerge, which has been described in the seminal paper of Akerlof on the market for lemons. ${ }^{20}$

Adverse selection will, in other words, arise if potentially responsible parties fail to disclose their true risk profile appropriately, which may endanger the narrowing of risk pools. Rogge holds that in Belgium the financial capacity to insure would be limited ${ }^{2.1}$ precisely because only bad risks would have a demand for insurance. If this can not be 'compensated' with good risks an incurable adverse selection would remain. ${ }^{22}$ Thus, "lack of demand has been matched by" lack of supply." 3

The literature has indicated that the appropriate remedy for both moral hazard and adverse selection is risk differentiation. We will come back to the importance of risk differentiation in environmental insurance below.

\section{Avoid Shifting the Risk of Causal Uncertainty}

There is another trend in liability law, which may indeed seriously endanger the predictability, and therefore the insurability, of certain risks. This concerns the tendency to shift the risk of causal uncertainty to enterprises (and therefore to their insurers) ${ }^{24}$ There are various situations that arose in Dutch case law to illustrate this tendency. The danger of shifting the burden of causal uncertainty to the enterprise is that the insurer of the specific employer or producer will be required to compensate for damage which, on the whole, had probably not been caused by the insured party. ${ }^{25}$ 


\section{Retrospective Liability}

There is one final danger, having to do with the structure of liability law, which may affect the insurability of (environmental) liability. This concerns those cases where liability expands in such a way that it is no longer foreseeable and that policy conditions can hence not be adapted ex ante. The question arises whether such a retrospective liability would lead to uninsurability.

At first sight one could argue that this certainly is the case. If the insurer were not aware that the behaviour of this insured party might potentially have been considered wrongful, no premium would have been charged for this risk, no preventive measures would have been required in the policy conditions and no reserves against losses would have been set aside. Indeed, insurance assumes that the insurer covers future risks, which are, at least to some extent, foreseeable. Insurance requires some degree of predictability. However, the mere fact that insurers of, say, industrial waste disposal sites in the 1960s have - as a matter of fact - not foreseen that the activities of their insured parties could lead to a liability in the future, does not make this event totally unforeseeable. The potential of a change in the scope of liability is an uncertain element which the insurer can, in principle, take into account ex ante. We are dealing here with the concept of insurer ambiguity' addressed by Kunreuther, Hogarth and Meszaros. ${ }^{26}$ If insurers could foresee the likelihood of a possible change in the liability system, they could react to uncertainty by estimating the probability that this event would occur and charge an additional risk premium to account for this legal uncertainty. In sum: in an ex ante perspective one can argue that nothing is totally unforeseeable or unpredictable; insurers can in principle cope with 'hard to predict' events such as the introduction of retrospective liability by charging an additional premium. However, in an ex post perspective this message is not very helpful for insurers who, at the time, did not take this risk into account and now have to provide cover to enterprises for risks which the insurers considered apparently unforeseeable. Hence, no additional premium was charged and no reservations were made, which explains why the retrospective liability, which is now laid down, say, for soil clean-up costs, leads to major problems for insurers. ${ }^{27}$ There is, hence, no problem of the uninsurability of retrospective liability as such, but only the simple fact that insurers did not take these risks into account when the policy was drawn up.

\section{Summary}

This brief overview of the conditions of insurability of the environmental liability shows that, provided that a number of conditions are met both in liability law and in the structure of the insurance policy, the environmental liability risk is insurable. This obviously is no surprise since one can notice 
liability insurance policies covering the environmental risk for a long time. However, the extent to which the liability risks are insurable is another issue. One could imagine that, e.g. the amount of the expected damage may be so large that it would exceed the capacity, even after using the possibilities of re-insurance and pooling. Also the unpredictability may be that large that insurers would be forced to charge a relatively high risk premium for which there might not be a willingness to pay. Some of these issues which may endanger the insurability of liability can, of course, be dealt with either in policy conditions or by the law. We cannot deal with these remedies for expanding liability any further in this paper. ${ }^{28}$ But one could point, e.g. at the fact that insurers could try to protect themselves (to some extent) against the risk of retroactive liability by changing the cover in time. It has been argued that a so called claims-made policy, holding that the claim for damages must have been received by the insurer during the period of insurance cover, would be an appropriate remedy to all these cases where there is a long time lapse between the moment that the tort occurs and the moment that the harm manifests itself. ${ }^{29}$ Moreover, the legislator could also choose efficient remedies. For instance, as far as the issue of causal uncertainty is concerned, the legislator (or case law) could introduce a proportionate liability rule, meaning that in case of uncertainty concerning the causal relationship, the victim can claim a proportion of its damage, equal to the likelihood that his loss was caused by a certain event. This proportionate liability has been defended as more efficient than the rigorous all or nothing approach or the reversal of the burden of proof. ${ }^{30}$ Thus a proportionate liability rule could enhance the insurability of the liability risk.

Within the scope of this paper we are, however, not interested in the possible devices to increase the insurability of environmental liability. The question I would like to turn to now is whether, taking into account the factors that affect the insurability of the environmental risk just discussed, one could argue that the environmental risk (but the same applies to other risks as well) would, under some circumstances, be better insurable under a first party than under a third party insurance system, such as liability insurance.

\section{Advantages of a First Party Insurance Scheme}

\section{Risk Differentiation: Theory}

The advantages of a first party insurance scheme are more particularly to be found at the level of risk differentiation. Let us first discuss the importance of risk differentiation more closely and then address the question why risk differentiation may be easier in first party insurance. 
George Priest has claimed that the adverse selection problem has caused an insurance crisis in the United States and that it can only be cured by an appropriate differentiation of risk 31 If the insurance policy requires preventive action from the insured party and provides for a corresponding reward in the premium this should give optimal incentives to the insured for accident reduction. Thus, risk pools should be constructed as narrowly as possible so that the premium reflects the risk of the average nember of that particular pool. ${ }^{32}$

A further differentiation of the risk is obviously only efficient as long as the marginal benefits of this further differentiation outweigh the marginal costs of such a differentiation. ${ }^{33}$ Risk differentiation certainly does not mean that insurers would have to use an individual tariff in each case. ${ }^{34}$ The possibilities for individual differentiation will inevitably also depend upon the value of the particular insurance policy. For mass insurance products with a low premium, risk differentiation can only take place in generall categories. In professional liability insurance of enterprises, however, the benefit of detailed differentiation, rewarding an enterprise for preventive action, may well outweigh the costs.

It is, thus, not difficult to make an economic argument in favour of effective risk differentiation as a remedy for a growing liability risk. If good risks are not rewarded for preventive action, either they will not have an incentive for prevention or they will leave the risk pool, and consequently the risk pools will be unravelled, as described by Priest.

\section{First Party Insurance: Theory}

Liability insurance is a third party insurance, whereby the insurer covers the risk that his insured (the potentially responsible party) will have to compensate a third party. A first party insurance is a system whereby the insurance coverage is provided and compensation is awarded directly by the insurer to the viction. Whether such a first party insurance can be considered as an efficient alternative for third party liability can not be answered in general terms. It depends to a large extent on the details of such a system and more particularly on the question whether the first party insurance is combined or not with the liability of the potentially responsible party.

The underlying principle in a first party insurance is that the insurance undertaking, in principle, pays as soon as damage occurs, provided that it can be proven that the particular damage has been caused by the insured risk. Payment by the insurance undertaking occurs irrespective of the fact whether there is liability. The arguments advanced in the literature in favour of first party insurance are that the transaction costs would be lower and that risk 
differentiation might be a lot easier. ${ }^{35}$ The reason is simply that with first party insurance the insurer covers directly the risk of damage with a particular victim or a particular site. The idea is that it is therefore much easier for the insured to signal particular circumstances, which may influence the risk to the insurer. The problem with liability insurance is that the insurer is always insuring the risk that his insured (the potential injurer) will harm a victim (a third party) of which the properties are unknown ex ante to the insurer. Moreover, under liability insurance there are lots of uncertainties, e.g. how the judge will interpret this specific liability of the insured. In the ideal world of first party insurance the insurer directly covers the victim, e.g. the risk. He can therefore monitor directly the risk and, in principle, provide a much better risk differentiation. ${ }^{36}$

If one would take the importance of risk differentiation and the risks of adverse selection as seriously as Priest did, the shift towards first party insurance seems to be most promising. One can - at least at theoretical level - understand why first party insurance would be beneficial to insurers: it is obviously much easier to control and assess ex ante the risk that a particular victim would suffer damage instead of assessing the risk that his insured potential injurer would cause harm to a third party and would thus be found liable. There are indeed many more uncertainties in third party liability, which could make an adequate risk differentiation more complex. Obviously within liability insurance risk differentiation is possible as well, in the sense that, as we have explained above, the insurer can adequately monitor whether his insured is a good or a bad risk (e.g. in the sense of taking preventive measures), which could then be rewarded with a lower or higher premium. But even if an ideal risk differentiation were applied, there are still many uncertainties in liability insurance. For instance, it will depend on the state of case law and the interpretation by judges whether the insured potential injurer will be found liable for a specific behaviour and a specific damage; it is apparently especially this uncertainty caused by judges, which the insurers dislike. Moreover with third party liability insurance it is ex ante not possible to know whether the insured injurer will cause damage to a very high income or a very low-income victim. That type of uncertainty can of course be avoided under first party insurance where - at least in the ideal situation - the victim chooses ex ante the insurance coverage he wishes according to his own demand and expected losses.

Notwithstanding these theoretical advantages, several questions still remain. More particularly the question arises how this scheme could be used to enhance the insurability of the environmental risk, which is the central topic of this paper. 


\section{Direct Insurance for Environmental Risks: A Few Questions}

Let us now see how such a first party insurance could be used as an alternative for liability insurance to cover environmental risks. Several practical questions will arise.

\section{First Party vs. Direct Insurance}

As we mentioned above, a first party insurance is based on the principle that the victim seeks coverage directly from the insurer. Such a system can, of course, hardly be applied to the full extent in the environmental sphere. Theoretically, in a pure first party insurance it is the victim who takes out insurance coverage and who therefore also pays the premium. Such a pure first party insurance scheme would probably not be very practical for environmental risks, unless one imagines industrial operators seeking coverage, e.g. for the pollution that may occur on their own plant. In that case, the operator would, in first party insurance, seek coverage for the damage he may suffer himself. Otherwise first party insurance would mean that private citizens who fear to suffer envirommental harm, e.g. in their garden, seek insurance coverage themselves.

However, there is an alternative which looks like first party insurance, and which is called direct insurance. In a direct insurance scheme one would imagine the potential polluter, e.g. the one who possesses a particular site, who seeks insurance coverage providing protection also to third parties who could suffer damage resulting from that particular site.

Such a direct insurance scheme is applied in some countries with respect to occupational health. In that case, e.g. the employer would take insurance coverage on behalf of his employees, who could claim directly on the policy. Under direct insurance the policyholder is not the victim, but the potential injurer. It is, however, not a liability insurance since the trigger to compensate is no longer liability, but the mere existence of damage.

For the environmental risk one could thus examine both a pure first party insurance, whereby potential victims cover losses themselves, and a direct insurance, whereby a potential polluter seeks insurance coverage also to the benefit of a third party (the victim). As we will see below, in practice there may be a combination of first party and direct insurance, in case a possessor of a particular site from which, e.g. soil pollution may occur, would seek coverage both for his own damage and for the damage which may be caused to third parties.

\section{Scope of Coverage and Causation}

The main difference between traditional liability insurance and either pure first party or direct insurance is that the coverage under the latter policies is no 
longer for liability. Hence, a consequence (and insurers claim an advantage) is that liability is no longer required to be able to claim on the policy. Traditional insurance would say that one would need an "accident". However, it is well known that, given the gradual nature of many pollution cases, these can hardly be considered as the sudden events, which are accidents. Therefore, in environmental insurance, damage will probably suffice "but it will be important to describe clearly what constitutes an insured damage which may gave a rise to a claim on the policy.

Depending on how this is formulated in the policy, the insured will have to claim that his damage is caused by the insured activity. In the hypothesis of a direct insurance, which benefits third party victims, problems could arise in case of nultiple causes. In that case the victim will obviously have to claim and prove that his damage was caused by the particular insured risk.

However, with environmental damage insurance, causation does not seem to be a major problem (other than that it may always be a problem in any environmental diability case as well). This is different in cases where first party insurance solutions are presented for health damage, such as in case of medical malpractice or for occupational diseases. In all of those cases the difficulty will be that the question will have to be settled whether the personal injury suffered by the victim is actually caused by medical malpractice or by an occupational disease. This type of causation issues, relating to the fact that it should be clear that the harm is caused by the insured risk, may also arise in environmental insurance, but seem less serious than in cases where personal injury is insured.

\section{Financing}

Although less interesting from a theoretical perspective, a practical question that will always arise at the policy level is who should pay for a first party or direct insurance scheme. A consequence of a pure first party system is that it theoretically is the victim who seeks insurance coverage himself and who therefore finances the first party insurance. To the extent that this victim is also the industrial operator who caused the risk., polluter and victim will be the same and it will effectively be the polluter who finances the insurance. If one would, however, adopt a first party insurance scheme for "innocent" victims, politicians would probably argue that now victims are forced to finance, e.g. the clean-up of the polluted soil in their own garden (by paying the premium for the first party insurance) whereas the polluter should pay for this. The answer would obviously be that if the first party insurer of the "innocent" victim were allowed a right of redress against the polluter, the polluter pays principle would still be satisfied and the polluter would still be given appropriate incentives for prevention. 
However, it is most likely that at the policy level discussions would primarily go in the direction of a direct insurance since under such a system the polluters finance the insurance coverage, also for the damage caused to third party victims.

\section{Prevention}

A question, which will obviously be asked, is how polluters are given appropriate incentives for prevention of environmental harm if the risk is fully covered under insurance. The answer here is obviously that this poses no difference with traditional liability insurance. All insurance systems potentially lead to the moral hazard problem, discussed above. But we equally indicated that an adequate risk differentiation can be the appropriate remedy to moral hazard. First party and direct insurance schemes were precisely advanced because they would enable a better risk differentiation. If that were the case, they could even lead to better results as far as prevention is concerned.

In practice the risk differentiation under first party and direct insurance would mean that, e.g. if a particular site were insured, the insurer would use all the ex ante monitoring and ex post devices to check the "ecological reliability" of the particular operator, which should provide optimal incentives for prevention. Hence, if the theoretical possibilities of risk differentiation are used in an optimal manner, first party or direct insurance schemes should cause no problem as far as prevention is concerned.

\section{Relationship With Liability Law}

An interesting issue, since liability is no longer the trigger for coverage, is of course the relationship to liability law. In many instances where first party of direct insurance schemes are advanced (such as in the areas of medical malpractice and occupational health), those schemes are often supposed to totally replace the liability system. One can notice, e.g. in the area of occupational health in many European systems a direct insurance scheme (providing coverage to all insured employees of one employer) with an immunity for liability of the employer, except in case of intent or gross negligence. In many countries these insurance systems are embedded in social security law.

A traditional argument, e.g. in the area of medical malpractice, against first party (patient) insurance schemes and in favour of tort law is that the incentives of the health care provider would be diluted without a liability system. ${ }^{37}$ At the theoretical level there would be no reason to grant immunity to the polluter even if, e.g. a mandatory first party or direct environmental insurance scheme were introduced. Even if a third party victim were compensated by the insurer, it would still be possible to use liability law (via the right of recourse) to provide appropriate incentives for prevention with the polluter. 
Therefore, there seems to be no reason to let a first party insurarice scheme replace liability law.

Notwithstanding this theoretical starting point, one can often notice in practice that first party or direct insurance schemes are only accepted (it is to say their mandatory introduction) if, e.g. in the area of occupational health the potential injurer (the employer) receives some kind of "compensation" in the form of a partial immunity of liability.

\section{Guarantee of Coverage}

Finally one could ask to what extent a first party or direct insurance scheme can provide a guarantee that funds will indeed be available at the crucial moment when they are needed, e.g. when a polluted soil needs to be cleaned up. This question has important policy implications and has several aspects. First of all, it relates to the question whether such a first party or direct insurance scheme should be introduced compulsorily. Indeed, the market could work out wonderful insurance devices, but if no operator would make use of those, there would still be no guarantee that, given the insolvency risk, funds would effectively be avaliable when they are needed. However, that is obviously not a particular problem of first party insurance, but a more general problem relating to the question whether at the policy level a duty to seek financial coverage for envirommental risk should be introduced. We will briefly address this question in Section 4. An issue, which is related to direct insurance, is whether one can provide for a direct right of action for a third party victim. This concens those situations where the insurance policy of the industrial operator provides that his coverage also extends to damage caused to third parties. Normally these third parties do not, given the privitiy of contract, have a claim on the insurance policy, unless they are formally made third party beneficiary of the policy, which provides for the direct insurance. The question hence arises whether one can see those third party beneficiary clauses in practice.

After having identified the potential benefits and several points of attention relating to first party and direct environmental insurance, let us now look at how these new policies are introduced in practice.

\section{ENVIRONMENTAL DAMAGE INSURANCE IN PRACTICE}

\section{A Trend Towards First Party Coverage}

At the end of the last section $\mathbb{I}$ indicated that although furst party insurance might seem very attractive at first sight at the theoretical level, since it might 
better enable a narrowing of risk pools, still a lot of questions arise, especially in its application to the environmental risk. It is probably best to examine these questions by looking at a practical example where a first party insurance of polluted sites has been implemented.

Before doing so it is probably important to stress that this exposé on first party insurance is not merely theoretical, but does indeed have a certain practical relevance. Indleed, the general liability committee of the Committé Européen des Assurances (CEA) has executed a study on first party legal obligations for clean-ups and corresponding insurance covers in European countries. ${ }^{38}$ This study shows that although the insurance situation between the European countries still differs to a large extent, first party insurance coverage seems to be available in several member states. ${ }^{3.9}$ In one country, more particularly in the Netherlands, the insurers have deliberately chosen to provide coverage of polluted sites on a first party basis. The idea is that the first party coverage should replace the traditional environmental liability insurance. Hence, it seems interesting to take a closer look at the insurance situation in the Netherlands.

\section{Environmental Damage Insurance in the Netherlands}

\section{Dissatisfaction With Existing Coverages}

Starting point for the concern of the Dutch insurers constituted the fact that all the theoretical problems I discussed above in Section 2 concerning the insurability of environmental liability, had also played a major role in the Dutch environmental practice. This had to do with the fact that the environmental risk is the example of a "long-tail risk", whereby the insurer today could be confronted with events which occurred in a distant past and would lead to liability of the insured now. Insurers held that this generally endangered the predictability of the risk.

Most of these problems were hence related to the fact that environmental harm does not constitute a sudden event, as is the case with most "traditional" accidents which are insured in liability insurance.

The Dutch insurance market therefore used to have the environmental risk covered through a variety of insurance policies, of which the most important were:

- the liability insurance policy (AVB) ${ }^{40}$ for the sudden risks and for occupational health risks which were related to the environment;

- the environmental liability insurance (MAS) for risks of a more gradual nature, non-including personal injury; ${ }^{41}$ 
- fire insurance for clean-up costs after fires (although the precise coverage of that policy was debated).

This environmental liability insurance was provided by an environmental pool, referred to as MAS. ${ }^{42}$ in this MAS 50 (re)insurers work together to cover the environmental liability risk. The MAS was hence constructed as an environmental pool, although the individual insurers, which were connected to the MAS, contracted individually the MAS policy under their own label.

There was, however, a lot of critique on that system, which can be summarised as follows. ${ }^{43}$

- First of all, the whole division of coverage between the AVB and the MAS was based on the idea that the AVB would cover the sudden risks and the MAS would cover the risks of a more gradual nature. As is well known, in practice it was not always possible to make a clear distinction between sudden and gradual risks, which led to uncertainties concerning the scope of the coverages of both policies. This was obviously the result of the fact that the Dutch insurers did not decide to exclude the environmental risk all together from the traditional liability insurance of companies (AVB).$^{44}$

- The environmental liability policy (MAS) was considered to be rather complex and had a very complicated procedure towards accepting insured. In addition, the policy was rather expensive and hence difficult to sell.

- A further problem was that neither the general environmental liability policy (AVB) nor the environmental liability insurance policy (MAS) provided any coverage for damage caused to the own site of the insured. This caused a problem for the insured, since according to the case law of the Dutch Supreme Court, companies could be held liable as well for a pollution of their own site. In addition the fact that pollution caused to the site of the insured was not covered inevitably again caused uncertainty concerning the scope of coverage. One could imagine cases whereby, e.g. polluted groundwater went from the site of the insured to a neighbouring site. This caused problems since the pollution to the site of the neighbour was insured whereas the pollution to the own site was not.

- Furthermore there were more uncertainties concerning the question whether clean-up costs were covered under the fire insurance policy. The fire insurance covers under the clean-up costs after fire also environmental damage that would have occurred, but only on the condition that there was a prior fire. In the fire insurance policy, no account was taken of the fact that after a fire also serious soil and water pollution could occur. Also, it 
was not always clear whether the soil clean-up costs, resulting from the fire, were also covered under the fire insurance.

- Finally there were obviously all the traditional problems related to environmental liability, such as the question whether a specific damage was indeed caused as a result of an insured risk. Also the case law concerning environmental liability extended in such a way in the Netherlands that this has not been foreseen by insurers. Hence, the liability risk was increasingly considered unpredictable and hence uninsurable as far as environmental harm was concerned.

\section{Environmental Damage Insurance: Main Features}

This led the Dutch insurers association to present in 1998 a new product, being the environmental damage insurance (MSV) ${ }^{45}$ This policy is available now since I January 1998 and it takes a revolutionary different approach than the traditional environmental liability insurance. ${ }^{46}$

This new environmental damage policy provides for various new elements. First of all it provides an integrated coverage of all the environmental damage which occurs on or from the insured site. Prerequisite is that it concerns pollution of the soil or of the water. The integrated coverage means that the new environmental damage insurance will replace the traditional pollution insurance (for sudden pollution) in the AVB and the liability insurance of the MAS (for graduall pollution).

The whole idea is that this coverage constitutes a direct insurance. In other words, the insured site is insured, even when clean-up costs have to be made on the site of a third party. Coverage takes place, as soon as the insured site is polluted as the result of the insured risk, irrespective of the fact that the insured could be held liable for the damage or not. In some cases the third party (the victim), moreover, receives a direct action on compensation on the basis of the environmental damage insurance policy. The trigger for compensation under this policy is therefore no longer tort law, but the insurance policy as it has been concluded between the insured and the insurance company. This, therefore, typically is a first party insurance or, as it is called in the Netherlands, a direct insurance. It is direct insurance to the extent that it also benefits third parties. It is indeed not the third party victim who purchases insurance (although the insured may be the victim), but someone who has responsibility for a site on or from which water or soil pollution may occur. The policy benefits third parties as well, at least when this is provided in the policy.

Obviously the environmental damage insurance can not set aside tort law, but the main advantage according to Dutch insurers is that the coverage is not triggered on the basis of liability. The advantage from the victim's point of 
view is obviously that coverage can be provided more rapidly and probably at lower transaction costs than through the court cases which are necessary as a result of liability law.

The environmental damage insurance as provided by the Dutch Insurers Association constitutes of several categories with different policies. The insured can opt for various insurance policies. This obviously shows that indeed first party insurance better enables an optimal risk differentiation since every insured will be able to purchase insurance coverage according to his own preferences. The damage on the insured location itself is insured. This at least provides coverage for clean-up costs and this is rather broadly defined. Also costs for the repair of damage are included. Soil pollution, which is also envisaged, obviously falls within the environmental damage insurance. Note, however, that under this policy it is only the costs of "clean-up" which are covered. ${ }^{47}$ Also the damage caused from the insured site and suffered by third parties is covered. This obviously provides a broader scope of protection.

The insured remains in principle fully liable, although the third party (beneficiary) that would be protected under the new MSV policy could claim directly on the policy and would hence, in principle, not have an interest in using liability law. However, it might be that the insured has taken too limited coverage and that in that particular case the third party would still (have to) use liability law. In that case the liability itself is not covered (and an insolvency risk remains), but the MSV policy provides for legal aid assistance in a couple of specific cases. ${ }^{48}$ This is, e.g. the case if the sum which is insured under the MSV coverage would not be sufficient, e.g. to pay for the clean-up costs incurred by the government. Or in case a third party would choose the liability law instead of direct action under the MSV policy. ${ }^{49}$

The main feature of the new environmental damage insurance provided in the Netherlands is obviously that it is no longer a liability insurance, but only a first party (or direct) insurance. The advantage for the insurer (and for the insured) is that the difficult road of liability law is excluded. Whether liability law will still be used is uncertain. Third parties could still use liability law, although it is obviously easier for victims to use the direct action provided under the MSV policy. There is, however, one important weakness, which unavoidably remains, being the fact that the environmental damage insurance is not compulsory. Hence, there may remain situations where companies in the Netherlands have purchased no insurance coverage at all or situations where only a basic coverage was taken for damage on the particular site, but only to a limited extent for damage to third parties. ${ }^{50}$ In those cases, third parties claiming against the responsible party might still be confronted with an insolvent polluter. Moreover, the new MSV regime is exclusive, meaning that 
the coverage for (sudden) soil and/or gound water pollution has now been removed from the liability insurance policy. This means that if an insured would, e.g. only have taken an MSV coverage for the insured site and a loss would occur to a third party on another site, this third party would probably use liability law against the polluter. In that particular case the polluter can not call on his general liability insurance (AVB) since the environmental risks have now been completely removed from that policy as a result of the entering into force of the MSV ${ }^{51}$

But that can obviously hardly be considered a weakness of the system of first party insurance: the insured obviously does not get more than what he pays for. Since the MSV is a general policy with a lot of options for the insured, premiums and amount of coverage can vary. The type of costs which are insured are, however, identified in the general policy and accordingly to the CEA study on first party insurance the total amount of coverage available under this new environmental damage insurance in the Netherlands would be 25 million Dutch guilders.

\section{Evaluation}

Mixed first party and direct insurance. If we turn back to the specific questions relating to first party/direct insurance one can notice that the Dutch scheme is apparently a mix of first party and direct insurance. It is principally a first party insurance in the sense that the insured site of the potential polluter is covered. It is also a direct insurance since the policy provides that not only the damage on the insured site itself is covered, but also the damage suffered by a third party.

The advantage for the insured is clearly that this first party insurance now provides coverage for the damage on the site of the insured as well. That is a major change compared to the past. Very often public authorities forced the polluters to clean up their own polluted soils. Formally this was not constructed as liability and therefore no insurance cover was available. As far as the insurance policy is concerned, it also covers the damage suffered by third parties, it effectively functions as a liability cover.

The trigger for coverage is no longer liability, but damage. There is a clear causation requirement in the policy, since it requires that the pollution must be the direct and exclusive result of an emission caused by one of the insured risks. Moreover, only the costs of remediation of the insured site are covered, which excludes the uncertainties involved with assessing environmental damage.

Adwantages. As far as prevention via an optimal risk differentiation is concerned, insurers obviously claim that this policy for them has the major advantage that 
they can adequately control ex ante the quality of a particular soil and the production methods applied by the insured. On that basis an adequate assessment of the risk can be made.

However, some company lawyers have been critical of this new insurance product. They argue that in practice insurers are so critical in providing coverage that effectively only the very good risks would be able to receive coverage. ${ }^{52}$ Hence, they claim that one cannot blindly argue that the environmental damage insurance would be a remedy for all insurability problems concerning the environmental risks. Indeed, a flip side of an effective ex ante monitoring is obviously that insurers could chose either only to cover the good risks or to cover bad risks only for a high premium. But one can hardly reproach the insurers to apply insurance economic principles correctly.

Moreover, the environmental damage insurance introduced by the Dutch insurers is a completely voluntary system, introduced without any government interference. A consequence is then also that the liability law is not affected by this regime at all. Victims suffering harm as a result of soil pollution can still sue the polluter. If his insured has accepted the possibility for third parties to claim, the victim can even claim directly on the policy as third party beneficiary. If, on the other hand, the MSV policy did not contain a third party beneficiary clause, the victim will, just as is the case today in the Netherlands, have to sue the liable polluter. A problem in that case is, however, as we indicated above, that the MSV is supposed to replace the liability insurance, meaning that a liability insurance will no longer be available, at least for the environmental risks covered under the MSV.

According to information provided by the Dutch Insurance Association this new product would work remarkably well. They claim that the interests of enterprises in this new environmental damage insurance is much larger than in the traditional environmental liability insurance. Whether this new product is actually a success yet is more difficult to judge. There is, however, undoubtedly an increasing interest of industry for this new environmental damage insurance. The fact that, hence, a wider financial security for environmental damage is provided in the Netherlands as a result of this product should definitely be considered as positive. Moreover from the victim's (mostly the government) perspective, the fact that the environmental damage insurance provides for a direct action for victims should be considered as positive as well. However, one should note that this third party action right onlly applies if the insured has accepted this.

Moreover, the advantage for the insured is that under this environmental damage insurance, also damage caused to his proper site is covered, which was obviously not the case under liability insurance. ${ }^{53}$ If, at a policy level, one would 
therefore conclude that an environmental liability system should be combined with some form of guarantee that financial security is available one should at least leave the option open to industry to provide this financial security via environmental damage insurance. The Dutch example shows that this first party type coverage seems able to meet that end ${ }^{54}$ Moreover, the example seems to be followed in other countries as well. ${ }^{55}$

Disadvantages. However, there are inherent limitations to this new environmental damage policy as well. First of all, one should note that this new insurance product only applies to soil pollution, ground water pollution and the subsequent remediation costs. It is therefore not a solution in case of other types of environmental harm like noise, surface water pollution or air pollution. But obviously it is also more difficult to apply liability law to those types of environmental damage as well.

Another point of criticism is that the amount of coverage that would be available seems to be relatively low. The CEA study reports that the amount of coverage available would be 25 million Dutch guilders. This would be sufficient to cover the average clean-up costs in case of soil pollution, but not for the larger scale cases. However, in practice, policies are not always awarded for this maximum amount of 25 million.

The fundamental question one can also ask at the policy level is whether the introduction of this new environmental damage insurance was really necessary to deall with the uncertainties of environmental liability, as the Dutch insurers claimed. One could argue that the tricky aspects of environmental liability, such as causal uncertainty and the long-tail risks could be dealt with either by the legislator or through adequate policy provisions. Note that, as a reaction to the long-tail risk caused under liability insurance, the claims made coverage was introduced. But this also applies in the MSV. Moreover, the risk differentiation may theoretically be easier in first party insurance, but if liability insurers would monitor potential polluters adequately (it is doubtful whether that happened in the past) the risk differentiation in environmental liability could be as adequate as in first party insurance. One has the impression that the real reason for the Dutch insurers to move to the environmental damage insurance was that they wanted to exclude the uncertainties having to do with the involvement of the judge (will there be wrongfulness, liability in this particular case? Will he accept causation or not?).

The insurers may now have excluded many of these uncertainties, but these will remain in existence for the polluters who are still fully exposed to environmental liability. This leads to a particular tricky aspect of the new regime, which really is a source of worry. Here I refer to the fact that this 
new MSV is supposed to replace the general liability insurance, at least for the environmental risks covered under the MSV. As a result of this, industrial operators in the Netherlands today no longer have the possibility to obtain liability coverage for their environmental risks. Third parties who suffer harm may be protected under the new MSV, but only under the assumption that the MSV coverage is sufficient to cover their losses. If this is not the case, the third party will simply have to use tort law and bring a lawsuit against the polluter. But then the problem will arise that this polluter is no longer covered under liability insurance. The victim may then find his defendant to be judgement proof.

Therefore, at the policy level we should examine whether it would not be necessary to introduce a compulsory insurance scheme, be it liability or first party based. In addition, the fact that the Dutch insurers are collectively moving from liability to environmental damage insurance raises questions concerning the competition on the insurance market. These aspects deserve separate attention in the next section.

\section{POLICY ASPECTS}

At the end of the previous section we concluded on the basis of the Dutch example with the environmental damage insurance that neither this new mechanism, nor the traditional liability insurance, do provide an adequate protection against insolvency. This, hence, merits some attention for the more general issue, whether a duty to provide financial security should be introduced for environmental harm (A). In addition, we came to the remarkable finding that apparently in the Netherlands in the future, only the new environmental damage insurance will be provided on the market and no longer liability insurance for environmental risk. This poses questions concerning the importance of an adequate competition policy on insurance markets (B).

\section{Compulsory Insurance?}

\section{Introduction}

We have to consider carefully the risk that a potential polluter would simply chose a "hit and run" strategy, whereby he would pollute, irrespective of the potentiall liability, since the liability rule could not affect him, given insolvency.

In legal doctrine, compulsory liability insurance is often advanced as a means to protect the innocent victim. ${ }^{56}$ The duty of an injurer to purchase liability insurance would be a good way to protect victims against the insolvency of the injurer ${ }^{57}$ Economists on the other hand see, as we mentioned above, different 
benefits of liability insurance. It is an instrument to increase the utility of a risk averse injurer. Whereas economists would therefore see liability insurance mainly as an instrument to serve the interests of the injurer, lawyers tend to rely more on the victim protection argument. Of course these views do not necessarily contradict each other. Sometimes they can go in the same direction in fawour of a duty to introduce liability insurance. Let us now address the question under what circumstances the purchase of insurance should be made compulsory.

\section{Economic Arguments}

Increasing the expected utility. A first way to look at this question could be to turn back to the basic utilitarian literature on the benefits of insurance. ${ }^{58}$ If insurance is indeed, beneficial, since it removes risk from risk averse persons and thus increases their utility, are not these benefits that large that they warrant the introduction of compulsory liability insurance? A problem with this argument is that the degree of risk aversion varies. A Rockefeller will probably not be averse towards the risk of losing U.S. $\$ 1000$, but a low-income family father probably will be. The low-income father will therefore probably have a demand for insurance against this risk of a loss of U.S. \$1000, whereas a Rockefeller probably would not. This straightforward example makes clear that the introduction of a duty to insure might be inefficient in as far as it forces some people to purchase liability insurance that would normally not have a. demand for insurance. Insurance does not increase their expected utility. A generalised duty to insure might therefore create a social loss. Whether this is the case will, of course, depend upon the number of people that is actually harmed by the introduction of a duty to insure. This might indeed be outweighed. by the fact that others will certainly have a benefit from insurance. This, however, does in itself, not justify the need to introduce a duty to insure. These risk awerse individuals might indeed have purchased insurance coverage anyway. This means that the simple fact that insurance increases utility can as such not justify the introduction of a duty to insure as long as we assume that all individuals are perfectly informed about the risk to which they are exposed and the availability of insurance.

This argument also rather paternalistically assumes that insurance is, under all circumstances, beneficial to potentially responsible parties. The argument neglects the fact that, as we have explained above, discussing the basic theory of liability insurance, the insured has to pay a price to have the risk removed from him. This price will unavoidably be a lot higher than the actuarially fair premium, consisting in the multiplier of the probability $\times$ damage $(p \times D)$. Depending upon the efficiency of the administrative working of the insurance 
undertaking, a high or low amount of loading costs will be added and depending upon the degree of concentration on the market, a profit margin could also be added. In addition taxes may increase the premium as well. Moreover, we have indicated that if there is uncertainty concerning the risk, the insurer might compensate this insurer's ambiguity with a risk premium. In sum, the premium charged may well be a lot higher than the actuarially fair premium, this is the objective value of the risk. For some responsible parties this premium will still be attractive, but for others it may not. Moreover, some may choose a balanced approach of, e.g. self insuring a basic expected damage and only taking insurance for the excess loss. Compulsory insurance generally neglects the fact that the demand for insurance may vary according to the individual risk situation (and financial possibility) of every responsible party. Other things being equal, there is therefore no reason for a regulatory intervention solely based on the fact that insurance may increase expect utility. A regulatory intervention would have the disadvantage that it is counter to the more differentiated demand of the responsible parties. However, this assumes that the responsible parties have a knowledge about their exposure to risk, the availability of insurance and make a well-informed decision accordingly. If this assumption is not met, the question could again be raised whether insurance should be made compulsory.

Information problems. Information problems might arise in case the potential injurer cannot make an accurate assessment of the risk he is exposed to and the benefits of the purchase of insurance. An underestimation of the risk would in that case lead to the wrongful decision of the injurer not to purchase liability insurance. The legislator could remedy this information problem by introducing a general duty to insure. This information problem is probably a valid argument to introduce a generalised duty to insure for motor vehicle owners. Maybe the average driver of a car underestimates the benefits of insurance. If there would be no information problem and the legislator would nevertheless introduce a duty to insure because this would be "in the best interest" of the insured, this would of course be mere paternalism.

If empirical evidence would exist that most polluters greatly underestimate the costs of the environmental damage they may cause, and the probabilify that they will be held liable for this damage, this would then llead polluters to reserve too few resources to cover their potential liability. If these conditions are met, and one can indeed assume that polluters underestimate the cost of environmental damage, this information deficiency may be considered an argument in favour of compulsory insurance. But again, the policy argument based on information asymmetry relates merelly to the fact that the polluter 
would underestimate the potential benefits of insurance. There may, however, be another argument why the (uninformed) decision of a polluter not to insure may lead to underdeterrence. This policy argument is precisely related to the insolvency risk mentioned in the introduction.

Insolvency. Another reason to introduce compulsory insurance is indeed the argument often used by lawyers, being the insolvency argument. The argument goes that the magnitude of the harm will often exceed the individual wealth of an injurer, whereby a problem of undercompensation of victims will arise. Lawyers would, hence, push forward compulsory insurance as an argument to guarantee an effective compensation to the victim. This - more distributional - argument obviously may play a role in the context of environmental liability insurance as well. If an injurer would be found judgement proof and hence, e.g. a polluted site would be "orphaned" the cosits would be borne by society.

It is, however, also possible to make an economic argument that insolvency will lead to underdeterrence problems which might be remedied through insurance. Indeed, this so-called "judgement proof" problem has been extensively dealt with in the economic literature. ${ }^{59}$

Insolvency may, however; pose a problem of underdeterrence. If the expected damage largely exceeds the injurer's assets the injurer will only have incentives to purchase insurance up to the amount of his own assets. He is indeed only exposed to the risk of losing his own assets in a liability suit. The judgement proof problem may therefore lead to underinsurance and thus to underdeterrence. Jost has rightly pointed at the fact that in these circumstances of insolvency, compulsory insurance might provide an optimal outcome. ${ }^{60} \mathrm{By}$ introducing a duty to purchase insurance coverage for the amount of the expected loss, better results will be obtained than with insolvency, whereby the magnitude of the loss exceeds the injurer"s assets. ${ }^{61}$ In the latter case the injurer will indeed only consider the risk as one where he could at most lose his own assets and will set his standard of care accordingly. When he is, under a duty to insure, exposed to full liability the insurer will obviously have incentives to control the behaviour of the insured. Via the traditional instruments for the control of moral hazard, discussed above, the insurer can make sure that the injurer will take the necessary care to avoid an accident with the real magnitude of the loss. Thus Jost and Skogh argue that compulsory insurance can, provided that the moral hazard problem can be cured adequately, provide better results than under the judgement proof problem. This is probably one of the explanations why for instance for traffic liability compulsory insurance was introduced. Uninsured and insolvent drivers who have little money at stake which they may lose compared to the possible magnitude of accidents they may 
cause, may have little incentives to avoid an accident. Insurers might better be able to control this risk and could force the injurer to take care under the threat of shutting him out of the insurance. Thus, the insurer becomes under a duty to insure the licensor of the activity.

Indeed, this economic argument shows that insolvency may cause polluters to externalise harm: they may be engaged in activities, which may cause harm, which can largely exceed their assets. Without financial provisions these costs would be thrown on society and would hence be externalised instead of internalised. Such an internalisation can be reached if the insurer is able to control the behaviour of the insured. As we have shown above, when discussing how risk differentiation can be applied to environmental liability insurance, the insurer could set appropriate policy conditions and an adequate premium. This shows that if the moral hazard problem can be cured adequately, insurance even leads to a higher deterrence than a situation without liability insurance and insolvency.

Of course, this argument in favour of compulsory insurance relies on a few assumptions and conditions, which will be discussed in further detail below. One is obviously that the argument is only valid if moral hazard can be controlled adequately and insurers also have appropriate incentives to do so. Another condition is that the insurance markets should be competitive. But one can notice that indeed both from a legal and from an economic point of view the potential insolvency of the injurer is a problem since it can both lead to underdeterrence and to undercompensation. Compulsory insurance may remedy both problems since it may provide adequate victim compensation and - if certain conditions are met - remedy the risk of underdeterrence.

An issue, which merits attention, is that one should raise the question whether compulsory liability insurance is the best instrument to remedy the insolvency problem. Indeed, although one usually refers to liability insurance in this context, several alternatives may exist that might be able to cure the insolvency problem at lower costs. A first obvious alternative would be to turn to (compulsory?) first party insurance instead of third party liability insurance, as we have argued above.

In sum, one could argue that compulsory insurance might theoretically be an adequate means to remedy the insolvency problem. However, this should not necessarily be liability insurance, but may well be the first party or direct insurance, discussed in this paper.

\section{Potential Dangers of Compulsory Insurance}

Moral hazard. After having discussed these three basic criteria for compulsory insurance, two other points cannot remain to be undiscussed either. Firstly, one should remember that with insurance there will always be the moral hazard 
problem, discussed above. This means that even if a legislator decides to introduce compulsory insurance, he should not restrain the possibilities of an insurer to control the moral hazard problem. Otherwise compulsory insurance will create more problems than it solves. Nevertheless, there seem to be problems since the legislator often limits the possibilities to expose the insured to risk. Indeed, with compulsory insurance the duty to insure is often equal to the total amount of liability and deductibles are not allowed. Hence, the total risk is shifted to the insurer which means that the only instrument available for the insurer to cure the moral hazard problem is a monitoring of the insured. If this would seem difficult or very costly the introduction of compulsory liability insurance might indeed create problems. Shavell even goes as far as to state that if the moral hazard problem cannot be controlled, the only regulatory intervention with respect to insurance should be a prohibition of liability insurance. ${ }^{62}$ In any case an introduction of compulsory insurance does seem problematic if the moral hazard problem cannot be controlled adequately.

Concentration on insurance markets. A second, related, issue is that until now we assumed that insurance markets are perfectly competitive and that thus premiums and policy conditions will be nicely tailored to the individual needs and the behaviour of the insured in order to control moral hazard optimally. In practice, however, many restrictions on insurance markets exist. We will give examples below. If monopolistic premiums can be set, an insurer will have fewer incentives to align his premiums to the individual behaviour of the insured and thus there is less control of the moral hazard problem.

From a policy viewpoint it also seems highly problematic to make liability insurance compulsory on concentrated insurance markets. Indeed, in that case the inefficiencies on the insurance market would be reinforced by making the purchase of insurance compulsory. Also, here the interest group theory of government can of course explain why insurers might want to lobby in favour of compulsory liability insurance. If they can allready determine the supply side of the market through monopolistic premium setting all such insurers should strive for is that every possible injurer should be forced to purchase insurance coverage. Through this regulatory intervention a certain demand is then guaranteed as well.

Nevertheless, in practice, insurers are never enthusiastic concerning compulsory insurance, at least for the environmental risk. Cousy claims that this is related to the fact that as a matter of law under compulsory insurance the insurer can often not invoke defences against the third party beneficiary of insurance. Moreover there would be problems related to the implementation and actual carrying out of the obligation to insure. ${ }^{6.3}$ 


\section{Further Warnings}

Dependence upon insurance market. The refinements and potential dangers just presented show that although theoretically a compulsory insurance mechanism may be desirable, also for envinonmental liability more particularly to cure information problems and the underdeterrence risk as a result of insolvency, in practice one should be cautious with the advice to introduce compulsory insurance for environmental damage. There are some more reasons to formulate such a cautious warning. One is that the legislator should be aware of the fact that as soon as it introduces compulsory insurance, it becomes dependant upon insurers to fulfil this duty to insure. The practical possibilities of an effective enforcement of a duty to insure will obviously to a large extent depend upon the willingness to insure on that particular market. It will ultimately be the insurance market who will decide whether they are willing to cover a certain risk. This may in the end lead to the undesirable situation that the legislator would introduce a duty to take out compulsory insurance, but that the market would refuse to provide such coverage. Introducing a duty to insure leads to a high reliance of the policy maker upon the insurance market. This seems to have led to problems with the German Environmental Liability Act of 1990 (Umwelthaftungsgesetz) which requires the owner of an installation that can cause significant damage to take out liability insurance or to have sufficient financial guarantees. ${ }^{64}$

One should indeed realise that if one makes the availability of insurance coverage a prerequisite for the operation of an enterprise, insurance undertakings in fact become the licensor of the industry, which may be questionable from a policy point of view. ${ }^{65}$ In fact the insurer becomes the tenvironmental policeman". 66 If that means, however, that the insurer, as a "policeman" controls the ecological performance of the insured company, there is of course nothing wrong with that. It may only be problematic if insurance companies will effectively be able to decide which companies may exercise their activities. This problem obviously especially arises in a monopolistic market.

This may, moreover, cause practical problems. Imagine that an insurer has stipulated in the policy conditions that coverage will be excluded in case of non-compliance of the insured written mandatory government regulation. This may well be, as we have suggested above, an effective instrument to control moral hazard. If, however, an accident happens under compulsory insurance the insured will not be able to call on this exclusion ground vis a vis the thind party beneficiary of the liability insurance policy. The fact that defences in the insurance contract are not opposable to third parties is a well known problem under compulsory insurance. The insurer will thus have to compensate the victim and may have a (statutory or contractual) legal right of recourse against 
the insured, provided that the latter is solvent. This is, as we explained, one of the reasons why insurers are reluctant against compulsory insurances.

Necessity of cooperation with insurers. One could obviously argue that these problems can be remedied if a good cooperation takes place between the policy maker and the insurance world, whereby the insurance world would inform the policy maker on the insurability of environmental damage. However, practice has shown that information provided by insurers concerning the insurability of a certain risk of with respect to the avalable amounts of coverage may not always be reliable. Below we will discuss the example of the Dutch insurers who decided collectively that the flood risk would be uninsurable. In fact it was only this monopolistic decision that caused the uninsurability.

There seems to be a trade off in that respect: introducing a duty to insure without any cooperation with the insurance world (which may have been the case in Germany) may lead to the catastrophic result that the government forces industry to take out a certain insurance coverage, whereby the market would not be willing to respond with the provision of such a coverage. However, a close cooperation between the insurers (usually represented via one insurance association) and the government only increases the risk of high concentration on insurance markets.

Envirommental liability insurance "grown up"? A further problem is that the policy maker should equally realise that today insurance coverage for environmental harm is still a relatively young and inexperienced branch. If a differentiated offer of insurance policies is limited, one could again question whether it makes sense to introduce a mandatory insurance if such coverage could only be found to a limited extent (or without sufficient competition) on private insurance markets. Of course, the limited availability of insurance cover for the environmental risk today is to a large extent caused by the adverse selection problem: since too little companies had a demand for insurance an optimal risk spreading (via the law of large number) is not possible. ${ }^{67}$ Moreover, only the bad risks will have a demand for insurance, which precisely causes the adverse selection problem. Hence, one could naively argue that this can be cured by forcing all polluters, good and bad risks to take insurance coverage. However, it seems strange to cure the limited availability of insurance for environmental risks, which may largely be due to its difficult-to-insure-nature by forcing all polluters to purchase coverage.

In this respect we can refer to the fact that a risk differentiation in environmental insurance in Europe still stands at the beginning of its possibilities and that far more possibilities exist to relate policy and premium conditions in an 
appropriate way to the ecological reliability of firms. Hence, one can really question whether today insurance firms are yet able to differentiate environmental risks in such a way that one can argue that moral hazard can be controlled optimally on competitive insurance markets. The cure to these problems is obviously not to make a poorly functioning insurance system compulsory.

Duty to accept? Obviously one could naively react with the suggestion that if insurance markets refuse to provide appropriate coverage, the policy maker should not only introduce a duty for industry to take out mandatory coverage, but also a duty for insurance companies to accept. Such a duty to accept would, so it could be argued, at the same time remedy the risk that the insurance undertakings would de facto become the licensors of industry. However, introducing a duty to accept certain industries as insured seems like an extremely dangerous path to go, given the importance of an effective control of moral hazard. One important instrument of insurers to control moral hazard is precisely to have the possibility to monitor ex ante the risk, which a particular insured may pose. This could ultimately lead an insurance undertaking to the decision that it considers the environmental risk a particular industry poses as too high. A logical consequence of the wish to have an optimal control of moral hazard should be the right of insurance undertakings to freely decide which potentially responsible parties to insure and which not. A duty to accept certain risks seems therefore to collide with the basic principles, which have to be respected to guarantee an effective functioning of insurance markets.

\section{Policy Recommendation}

From the above it follows that there are, indeed, arguments in favour of introducing a compulsory insurance scheme, based on possible information deficiencies and on the risk of underdeterrence as a result of insolvency. However, already theoretically, one can point at dangers as well, more particularly the fact that insurers may become the licensors of the activities which may cause the environmental harm. This should not be remedied through a duty to accept, since this may cause incurable problems of moral hazard. All these considerations are therefore arguments for a policy maker to be extremely cautious with the introduction of a regulatory duty to purchase insurance coverage.

From this discussion on compulsory insurance follows probably an important conclusion. Although it may be important from a theoretical perspective to introduce a duty for the permit holder to secure appropriate means, it seems more appropriate to look for a flexible system whereby the licensing administrative authorities could judge in individual cases whether 
the obligation to provide financial security has been met. Such a system, whereby it is left to the administrative authorities to decide the form and amount of the financial obligation seems more flexible and entalls less of the risks and dangers of a generalised system of compulsory liability insurance.

But to reiterate clearly: the principle that liability should be covered through some form of financial assurance (not necessarily insurance) should be laid down in legislation. The authorities would then only have to fix the amount: taking into account the expected damage (this will allow for an individualisation and differentiation), and they would have to check whether the type of financial assurance offered by the potentially responsible party will be adequate to meet his financial obligations. Here maybe the example of the Flemish Interuniversity Commission can be useful ${ }^{68}$ The draft decree on environmental policy chooses, not to introduce a compulsory insurance, but provided that an obligation can be introduced for the licensee of a classified activity to provide a deposit in order to guarantee that specific obligations shall be complied with. As proposed by the Flemish Interuniversity Commission, the authority to fix the amount and to control the offer of financial assurance could be the one who grants the licence at the start of the operation of the activity. ${ }^{69}$ In terms of the IPPC Directive this would be the competent authority granting the permit. ${ }^{70} \mathrm{By}$ the way, Sweden has a compulsory insurance scheme for environmental harm which would be working pretty well. Some argue that this is precisely the case because this Swedish scheme is not based upon liability insurance, but upon direct insurance. ${ }^{71}$

In sum, the liability regime should be combined with some kind of obligation to provide financial security if one can assume that an insolvency risk may emerge. But:

- this financial security should not necessarily be liability insurance;

- the policy maker could indicate that a wide variety of mechanisms may be used to provide this financial security;

- the type of financial security provided should not be regulated in a general matter, but it adequacy may be assessed, e.g. by the administrative authorities who can require financial security as a condition in the license;

- at the same time the administrative authorities can equally determine the required amount of financial security on a case by case basis;

- there should certainly not be the introduction of a duty to accept risks on liability insurers, since this may have negative effects on the control of moral hazard:

- the administrative authorities imposing such a duty to provide financial security should make sure that sufficient varieties of financial securities exist 
on financial and insurance markets in order to avoid that governments or administrative authorities would become dependant upon the financial or insurance industry, which would then effectively become the licensor of industrial activities;

- the proposed regime corresponds with the proposals made by the Interuniversity Commission in the Flemish Region. These proposals were promulgated as the result of information provided by insurers and the regime moreover applies in the Flemish soil pollution decree. Hence, there is some empirical evidence, which shows that such a ballanced and mitigated obligation to provide financial security in limited cases may work effectively.

\section{Competition Policy}

\section{Imporlance of Competition on Insurance Markets}

We noted that the Dutch insurers association advised all their members to move towards environmental damage insurance and to let the policy replace the traditional environmental liability insurance. The effect could be that liability insurance for environmental risk is no longer available on the Dutch market. Moreover, in the past the Dutch insurers association took an opposite position with respect to flood risk: it argued for a long time that these risks were uninsurable and even prohibited their nembers to provide coverage for flood risks. Above we showed that these anti-competitive pressures may be particularly dangerous since they will obviously limit a widle and differentiated offer of a variety of financial and insurance products to cover the environmental risk. It is interesting to have a closer look at some of these practices, given the fact that the boundaries of the application of European competition law to the insurance industry have recently been outlined in a report of the European Commission with respect to the functioning of a regulation concerning the insurance industry. ${ }^{72}$ Certain practices with respect to environmental liability insurance are explicitly addressed in this report and therefore merit some attention here.

I should first of all point at the fact that Commission regulation no. $3932 / 92$ of 21 December 1992 exempts many cartel agreements in the insurance world from the prohibition under (old) article 85 (3) of the EEC treaty, provided that certain strict conditions were met. ${ }^{73}$ Already this exemption has been heavily criticised by law and economics" scholars, who argued that competition policy should be fully applied to insurance markets as well. They argued that an exemption from competition policy may lead to a premium increase. lower product differentiation and potentially even to an increase of accident costs 
(because the incentives to control moral hazard would be reduced). ${ }^{74}$ But these criticisms will probably not affect the insurance industry who can benefit from the exemption. However, the recent report to the European Parliament of 12 May 1999 made clear that some current practices may not fall under the conditions for the exemption from the cartel prohibition:

\section{Binding Decisions}

The Dutch insurers association had issued in the $1950 \mathrm{~s}$ a, literally called, "binding decision" for all of its members, prohibiting them to insure the flood risk and the earthquake risk (the latter being relatively small in the Netherlands with the exception of the area around southern Limburg). Their argument was that these risks were technically not insurable and that therefore all the members should refrain from covering those risks. The argument concerning the uninsurability seems highly doubtful, ${ }^{75}$ but also clearly violated the conditions of regulation $3932 / 92$. Consideration 8 preceding the exemption clearly states that standard policy conditions may, in particular, not contain any systematic exclusion of specific types of risk without providing for the express possibility of including that cover by agreement. This is repeated in article 7 (1) (a) of the exemption. In its report to the European Parliament of 12 May, the Commission explicitly discusses these binding decisions. ${ }^{76}$.The report states that as a result of the questions asked by the Commission, the Dutch association of insurers decided to bring its binding decisions in line with article 7.1 sub a by simply converting it into a non-binding recommendation, leaving each insurer free to extend cover" to flood risks. However, this example shows that noncompetitive practices are apparently not an exception in Dutch insurance practice.

\section{Standard Form Policies}

A point which inevitably needs to be addressed in the context of these changes in the environmental insurance structure in the Netherlands is to what extent these standard policy models are compatible with European competition policy. We already noticed that, e.g. concerning the liability insurance for companies in the Netherlands (AVB) a new model policy came into being in 1996 which bas been offered to the market. ${ }^{7}$ This AVB model policy suggested the change from a loss occurrence coverage to a clams-made coverage. ${ }^{78} \mathrm{Also}$, as has just been indicated, the Dutch insurers association decided to change the coverage of environmental risks from liability insurance to first party insurance.

The question which imevitably arises is, whether it is compatible with competition policy to formulate an advice via a standard policy which is de facto followed by the whole market. Again, this issue is covered by the 
exemption regulation $3932 / 92$ of 21 December 1992. Article 6 of the exemption regulation provides that the exemption shall apply to standard policy conditions on the condition that it is made clear that these policy conditions are purely illustrative and that they expressly mention the possibility that different conditions may be agreed upon. In addition, the standard policy conditions must be accessible to any interested person and provided simply on request. The standard policy conditions used by the Dutch insurers in environmental insurance certainlly can meet this test. Both the new insurance policy for liability of companies (AVB) and the environmental damage insurance (MSV) mention explicitly that they are merely illustrative and that it stands free to any individual insurer to deviate from the text or the contents of the pollicy model. ${ }^{79}$

Formally the standard policy conditions provided by the Dutch Insurers Association are hence compatible with the exemption regulation. Nevertheless, one cannot deny that the use of standard form policies will inevitably have an effect of restricting competition. Indeed, although these standard policy models all indicate that they are merely illustrative and that any insurer can deviate from them, it is today in the Netherlands almost impossible de facto to get any liability insurance for the environmental risks which are now covered under the MSV (more particularly for soil pollution). However, these concerns will probably not be a great worry to Dutch insurers, since the used standard policy forms can easily pass the test of the exemption regulation.

Indeed, the Dutch insurers association did not formally force all insurers not to prowide any liability cover for environmental risk any longer and the standard policies stipulate clearly that every insurer is free not to follow the recommendations made in the standard policy. Formally the Dutch practice is therefore compatible with the requirements of European competition pollicy. However, in practice one can notice that almost all insurers cooperating within the Dutch insurers association follow the recommendations in the standard policy in practice. The effect therefore is that no Dutch company will be able to purchase liability cover for soil pollution any longer on the Dutch market. The same is the case, by the way, for foreign insurance companies operating on the Dutch market. The only alternative for Dutch operators today is to seek liability cover abroad.

Even though formally complying with European competition policy, some scholars have pointed at the fact that this tendency to follow these recommended standard form policies leads to serious restrictions of competition in practice and to a reduced product differentiation. ${ }^{80}$

In sum: although we have argued that it is understandable that the Dutch Insurers Association wished to offer an environmental damage insurance 
on first party/direct insurance basis, it is, from a competition perspective, regrettable that the introduction of this new product was accompanied with the (in practice) abolition of environmentall liability insurance in the Netherlands, at least for the issues covered under the MSV. The effect therefore is a reduced variety of insurance products for environmental risk.

\section{CONCLUDING REMARKS}

In this paper I dealt on the one hand with a number of well-known problems which may endanger the insurability of the environmental risk; on the other hand special attention was given to a new environmental insurance product introduced recently in the Netherlands, but gaining popularity in other countries as well. The reason for giving that much attention to this new product, referred to as an environmental damage insurance, is that the insurers claim that many of the problems that arise when insuring the environmental risk are in fact problems related to environmental liabilify. In other words: they claim that the environmental risk would be better insurable if the risk could be insured on a first party basis. Many of the problems that appear under liability insurance would then disappear, or at least be reduced, so it is held.

From a theoretical perspective the Dutch insurers certainly have a point: already in 1987 George Priest claimed that the American liability and insurance crisis was caused by a shift from first party to third party insurance. The obvious remedy for him was then to move back from third party (liability) insurance trowards first party insurance. However, in reality the first party model seems indeed an appropriate remedy for problems in liability cover, but in fact only for just one aspect of the insurability of the environmental risk, being the issue of risk differentiation. Indeed, first party insurances are held to enable a better risk differentiation than traditional hability insurance. Of course this is an important issue since an adequate risk differentiation has always been advanced as the appropriate remedy for the dangers of moral hazand and adverse selection. But on the other hand, other problems concerning the insurance of environmental risk will remain. This concerns for instance the issue of a limited capacity in case of catastrophic environmental accidents, the risk of judges shifting causal uncertainty to an industrial operator and the danger of a retrospective application of liability laws. Indeed, also under first party insurance, capacity will not be unlimited; also a first party insurance requires a condition of causation (it must be proven that the damage was caused by the insured risk) and the problem of retroactive liability resulting from the "long-tail" character" of the environmental risk may be cured both under third 
party and under first party insurance (at least to some extent) by the introduction of a claims made cover.

The Dutch insurers introduced their new environmental damage insurance with great enthusiasm, claiming that they have now been able to increase the manageability and predictability of the risk. Their basic idea is that it is much easier to monitor and predict the potential of damage ex ante with one particular site, than to predict the chances that one operator may be held liable to pay damages to a third party. One important factor of uncertainty (the judge) has thus been excluded. Although one can understand the enthusiasm of the insurers and, to some extent, the corporate world (since under first party insurance they also receive coverage for their own losses), there are clearly disadvantages as well. The major disadvantage is not related at all to the fact that the first party environmental damage insurance would not be an adequate insurance product, but to the fact that the introduction of this new product was accompanied with the abolition of liability insurance for the environmental risk. As a result of this, some victims may not receive compensation any longer, at least in those cases where the damage insurance does not provide sufficient coverage and the polluter is insolvent. We took this finding to look at the more general policy question whether there should not be a duty to secure financial coverage for the environmental risk. Given the risk of insolvency we held that a serious problem of underdeterrence could arise which could be solved by introducing some obligation to provide financial security to cover the environmental risk. However, such a financial security should not necessarily be liability insurance. In that respect the environmental damage insurance may play a role again. But in any event, the administrative authorities should then control, e.g. by fixing a specific duty in licence conditions, that the type of security offered will indeed be adequate to cover the financial consequences of environmental damage that may be caused by that particular licensee.

Moreover, the finding that this new environmental damage insurance was introduced on the Dutch market as a standard policy caused some worries as well. Apparently the cooperation between insurers in the Netherlands is that close that, although formally the standard policy only is an "advice", in practice operators cannot obtain coverage for the liability risk (for instance on a result of soil pollution) any longer. This example shows that restrictions of competition on the insurance market may seriously limit product differentiation and thus endanger the insurability of the environmental risk. This shows that an effective competition policy is of utmost importance to guarantee that a large variety of efficient insurance policies is indeed available on the market for the environmental risk. Otherwise changes such a the one we discussed for the Netherlands could limit rather than enhance the insurability of the environmental risk. 


\section{NOTES}

1. See e.g. Spier, J. (Ed.). The limits of liability, keeping the floodgates shut, "The Hague; Kluwer, and Spier, J. (1996). De witdiende reikwijdte wan het aansprakelikheidsrecht, pre-advies Nederlandse Juristenvereniging.

2. Referring to the fact that the polluter on the one hand has to invest heavily to be able to comply witliz the conditions of a licence and on the other hand has to pay as well for the remaining environmental damage. See in this respect especially Bergkamp, L. (1999). De vervuiler betaalt dubbel. Antwerpen, Intersentia.

3. For a comment on this White Paper see Rice, P. (2000). From Lugano to Brussels via Aarhus: environmental liability White Paper published, Environmental liability, 39-45; and Rehbinder, E. (2000). Towards a community environmental liability regime: the commissions White Paper on environmental liability, Environmental liability, 85-96.

4. In another study, it has been held that provided that the economic principles of insurance are respected (such as some degree of forseeability and predictability of the risk) the mere fact of expanding liability should not as such endanger insurability. See Faure, M., and Grimeaud, D. (2000). Financial assurance issues of environmental liability, final version 4.12 .2000 , which contains an analysis of the insurability of the regime proposed by the white paper on environmental liability. This study has been made available electronically via the website of the Commission: http: Ihwww.europa eu int tcomlenvironment Viabilitylfollowup.htm

5. For a nice overview of alternatives. see Tyran, J. R., and Zweifel, P. (1993). Environmental risk intemalization through capital markets (Ericam): the case of nuclear power, Intemational Review of Law and Economics, 431-444; Radetzki, M., \& Radetzki, M. (2000). Private arrangements to cover large-scale liability caused by nuclear and other industrial catastrophes, The Geneva Papers on Risk and Inswrance, 180-195.

6. Priest, G. (1987). The current insurance crisis and modern tort law, Yale Law Joumal. $1521-1590$.

7. See Arrow, K. (1965). Aspects of the Theory of Risk-Bearing, Helsinki, Yrjo Jahnssonin Săätiö; and Borch, K. (1961). The Utility Concept Applied to the Theory of Insurance, The Astin Bulletin, 245-255.

8. See Shavell, S. (1987). Economic analysis of accident Law, Cambridge, Harvard University Press, 190.

9. Skogh, G. (1989). The transactions cost theory of insurance: contracting impediments and costs, Joumal of Risk and Insurance, 726-732.

10. Obviously these conditions cannot be dealt with in detail; the reader is referred for turther information to the literature cited in the foomotes. For an overview see Kunreuther, H., and Freeman, P. (2001). Insurability, environmental risks and the law. In: A. Heyes, (Ed.), The Law and Economics of the Enwironment (pp. 305-306), Cheltenham, Edward Elgar.

11. Monti rightly points out that the fact that there may be both factual and legal uncertainty . Monti, A. (2001). Environmental risk: A comparative law and economics approach to liability and insurance, European Review of Privare Law, 59-62.

12. Rogge, J. (1997). Les assurances en matière d'enviromement, Loose-Leaf, Kluwer, 4.

13. Kunreuther, H., Hogarth, R., and Meszaros, J. (1993). Insurer Ambiguity and Market Failure, Journal of Risk and Uncertainty, 71-87. 
14. Pauly, M. (1968). The Economics of Moral Hazard: Comment. American Economic Review, 531-545.

15. See Wagner, G. (1996). Versicherungsfragen der Umwelthaftung. In: M. Ahrens, \& J. Simon (Eds), Uwwelhaftumg, Risikostenerwng and Versichertung (pp. 104-105). Berlin, Erich Schrnidt Verlag.

16. See Shavell, S. (1979). On Moral Hazard and Insurance, Quarterly Journal of Econowics, 541-562.

17. Spence, M., and Zeckhauser, R. (1971). Insurance, Information, and Individual Action, Americam Economic Review, $380-391$.

18. Rea, S. (1982). Non-pecuniary loss and breach of contract. In: Jommal of Legal Studies, (pp. 35-53).

19. See van Eijk-Graveland, J. C. (1998). Verzekerbaarheid van opzet in her schadeverzekeringsrecht, Zwolle, Tjeenk Willink.

20. See Akerlof, $G$. (1970). The market for "lemons': quality, uncertainty and the market mechanism, Quarterly joumal of Economics, 488-500.

21. Although he mentions that some larger companies are (in 1996) able to get coverage up to 1 billion Belgian Francs.

22. Rogge, J. (1997). Les assurances en matière d'erwironnement, Loose-Leaf, Kluwer, 5.

23. Cowell, J. Compulsory environmental liability insurance. In: H. Bocken \& D. Ryckbost (Eds), Insirance of Environmental Danage, 327.

24. See Frenk, N. (1995). Toerekening naar kansbepaling, Nederlands Juristenblad, $482-491$.

25. Also Abraham, K. (1988). Envitonmental Liability and the Limits of Insurance, Columbia Law Review, (Vol. 88), 959-960; and Katzman, M. (1988). Pollution liability insurance and catastrophic environmental risk, Joumal of Risk and Insurance, 89-90.

26. Kunreuther, H., Hogarth, R., and Meszaros, I. (1993). Insurer Ambiguity and Market Failure, Joumal of Risk and Uncertainty, 71-87.

27. See also Zeckhauser, R. (1996). 19th Annual Lecture of the Geneva Association and Catastrophes, The Geneva Papers on Risk and Insurance, 5, who equally argues that retrospective liability may affect the predictability of risks; as well as Abraham, $\mathrm{K}$. (1988). Environmental Liability and the Limits of Insurance, Columbia Law Review, (Vol. 88), 957-959.

28. See further Faure, M., and Hartlief, T. (1998). Remedies for expanding liability, Oxford Jownal of Legal Studies, 18, 681-706.

29. See Faure, M., and Fenn, P. (1999). Retroactive liability and the insurability of long tail risks, Intemational Review of Law and Economics, 487-500.

30. Rosenberg, D. (1984). The causal connection in Mass Exposure cases: a public law" vision of the tort system, Harvard Law Review, 851-929; Shavell, S. (1985). Uncertainty over causation and the determination of civil liability, Joumal of Law and Economics, 587-609. Also the Dutch Attorney General Hartkamp defended a market share liability in the DES case (Tijdschrift voor Conswmentenrecht, 1992, 241-258). In addition Spier pleaded in favour of a proportionate liability for latent diseases in his inauguration address (Spier, I., Slaipende schade, Deventer, Kluwer, 1990), as did Akkermans, A., Proportionele aansprakelijkheid bij onzeker causaal verbana, Deventer, Tjeenk Willink, 1997, in his recent dissertation; Robinson, G., "Probabilistic causation and compensation for tortious risk", Joumal of Legal Studies, $1985,798$. 
31. Priest, G., o.c., 1521-1590. Priest has been criticized by Viscusi, who claims that there were other reasons for the product liability crisis in the U.S. than adverse selection on its own (Viscusi. W. K. (1991). The Dimensions of the Product Liability Crisis, Journal of Legal Strudies, 147-177).

32. Abraham, K., o.c. $949-951$.

33. Generally the question is whether the benefits of particularization outweigh their costs, which has to be addressed in tort law when a standard of care is defined (Posner, R., Economic Analysis of Law, 5th edition, New York, Aspen Law \& Business, 1998), but also when legal rules are made (Ehrlich, I., and Posner, R. (1974). "An Economic Analysis of Legal Rule-Making", Journal of Legal Studies, 257) or standards are set (Ogus, A. I. (1981). Quantitative Rulles and Judicial Decision Making. In: Burrows, and C. Veljanovski (Eds), The Economic Approach to Law (pp. 210-225). London, Butterworth; Ogus, A. I. (1994). Standard Setting for Environmental Protection: Principles and Processes. In: M. Faure, J. Vervaele, and A. Weale (Eds), Environmenial Standards in the European Union (pp. 25-37)).

34. On the costs of risk differentiation, see Bohrenstein, S. (1989). The Economics of Costly Risk Sorting in Competitive Insurance Markets, International Review of Law and Econonics, 25-39; and Wils, W. P. J. (1994). Insurance Risk Classifications in the EC. Regulatory Outlook, Oxford Jommal of Legal Studies, 449-467.

35. This argument is - again - especially advanced by Priest, G. (1987). The current insurance crisis and modern tort law, Yale Law Joumal, 1521-1590.

36. Many other law and economics scholars have pointed at the advantages of first party insurance. See, e.g. Bishop. W. (1983). The Contract-Tort Boundary and the Economics of Insurance, Joumal of Legal Studies, (Vol 12), 241-266; and Epstein, R. A. (1995). Simple Rules for a Complex World, Cambridge, Harvard Uniwersity Press, 221; and, in the product liability area Epstein, R. A. (1985). Products Liability as an insurance market, Journal of Legal Studies, (Vol. 14), 645-669.

37. See, e.g. Danzon, P. (1999). Alternative liability regimes for medical injuries", Geneva Papers an Risk and Insurance, 3-22, and see Koziol (1997). Die Arzthaftung im geltenden und kunftigen Recht, Haftungsrechtiche Perspektiven der Ärtlicher Behandlung. Linz, Universitatsverlag Rudolf Trauner, 21-35.

38. CEA, Study on first party legal obligations for clean-ups and corresponding insurance covers in European Countries, Paris, CEA, 21 October 1998.

39. See the summary tables in the CEA study, 32.

40. Aansprakelijkheidswerzekering bedrijwen.

41. See on that policy Wansink, J. H. (1985), De nieuwe milieuaansprakelijkheidsverzekering, Milien en Recht, 98.

42. Milieu-aansprakelijkheidsverzekering Samenwerkingsverband.

43. I am grateful to Mr. P. A. J. Kamp of Nationale Nederlanden who provided us some further insights for the reasons behind the changes towards first party insurance in the Netherdands.

44. For further details on these difficulties see Wansink, J. H. (1997). Hoe plotseling en onzeker is de verzekeringsdekking voor millieuaansprakelijkheidsrisico's? In: Miscellanea. JurisConsulto vero dedicata, Essays offered to Prof.Mr. J. M. van Dunné, Deventer, Kluwer, $451-460$.

45. Milieuschadewerzekering.

46. For a good description of the new policy see Wansink, J. H. (1999). Verzekering en milieuschade als gevolg van verwoer/opslag van gevaarlijke stoffen, Tijdschrift voor 
Milieuaansprakelijkheid, 77-82 as well as Janssen, C. A. (1998). Aansprakelijkheid woor millieuschade en financiële zekerheid naar toekomstig recht: nieuwe oplossingen. Nederlands Recht. In: L. F. Wiggers-Rust \& K. en Deketelaere, (Eds), Aansprakelijkherd voor milieuschade en financiële zekerheid, Die Keure - Vermande, $111-112$ and Drion, P. J. M. (1998/2). Milieu onder ến dak: milieuschadeverzakering (MSV), Verzekeringsrechtelike Berichten "19-21.

47. Article 11.1.1. defines as the scope of coverage: "Insured are the costs of remediation of the insured site. This remediation must apply to a pollution which is the direct and exclusive result of an emission, caused by one of the insured risks...".

48. This legal aid coverage, however, is not applicable if the insured took a low amount of coverage.

49. See Wansink, J. H. (1999). Verzekering en Milieuschade als gevolg van verwoer/opslag van gevaarlijke stoffen, Tijdschrift voor Miliewaansprakelijkheid, 81 .

50. In principle, damage caused from the insured site to third parties is always covered, but the amounts of coverage may be limited.

51. Wansink, J. H. (1999). Verzekering en Milieuschade als gevolg van vervoer/opslag van gevaarlijke stoffen, Tijdschrift woor Milieuaansprakelijkheid, $8 \mathrm{l}-82$.

52. Niezen, J. (1998). Nieuwe milieuschadeverzekering - geen panacee, Milieu en Recht, 114.

53. Cousy, H. Recent developments in environmental insurance. In: F. Abraham, K. Deketelaere \& J. Stuyck (Eds), Recent Economic and Legal Developments in European Envirommental Policy (p. 240).

54. Also Bergkamp argues strongly in favour of first party and against envirommental liability insurance (Bergkamp, L. (2000). The Commissions White Paper on Environmental Liability: A weak case for an EC Strict Liability Regime, European Environmental Law Review, 112-114).

55. Ranson reports that also in Belgium a "direct" environmental insurance would be offered which would also cover gradual pollution (but would exclude ecological damage). See Ranson, D. (2000). Verzekering van millieuaansprakelijkheid, Milieu- en Energierecht, 68. The new policy would cover, like the Dutch example, also remediation costs. It would be offered by AIG and would provide coverage up to 1 billion BEF (see Kerremans, H. Aansprakelijkheid voor Milieuzorg en verzekeringsmogelijkheden in Milieuzorg in de Onderneming, I., Juridische, fiscale en arganisatorische aspecten, Antwerpen, Standaard, 537-583).

56. Compulsory environmental liability insurance is proposed by several scholars, including Cowell, J. Compulsary environmental liability insurance. In: H. Bocken \& D. Ryckbost (Eds), Insurance of Envirommental Danage (pp. 317-330); and Monti, A. (2001). Environmental risk: A comparative law and economics approach to liability and insurance, European Rewiew of Private Law, 65.

57. Some even argue that mandatory financial responsibility could help implement the precautionary principle by ensuring availability of resources to meet the costs of any future environmental damage, so Richardson, B. J. (2000\%. Financial Institutions for Sustainability, Environmental Liability, 61.

58. Arrow, K. (1965). Aspects of the Theory of Risk-Bearing, Helsinki, Yrjo Jahnssonin Sảatiö; Borch, K. (1961). The Utility Concept Applied to the Theory of Insurance, The Astin Bulletin, 245-255; Borch, K. (1963). Recent Developments in Economic Theory and their Application to Insurance, The Astin Bulletin, 322-341; and Pratt, J. (1964). Risk Aversion in the Small and in the Large, Econometrica, 122-136. 
59. More particularly by Shavell, S. (1986). The judgement proof problem, International Review of Law and Economics, $43-58$.

60. Jost. P. J. (1996). Limited liability and the requirement to purchase insurance, International Review of Law and Economics, 259-276. A similar argument has recently been formulated by Polbom, M. (1998). Mandatory Insurance and the Iudgement-Proof Problem, Mnernational Review of Law and Economics, 141-146; and by Skogh, $\mathrm{G}$. (2000). Mandatory Insurance: Transaction Costs Analysis of Insurance. In: B. Bouckaert, and G. De Geest (Eds), Encyclopedia of Law and Economics (pp. 521-537). Cheltenham, Edward Elgar. Skogh has also pointed out that compulsory insurance may save on transaction cost.

61. See also Kunreuther, H., and Freeman, P. In: A. Heyer, (Ed.), The Law and Economics of the Environment, 316.

62. Shavell, S. (1986). The judgement proof problem, twtemational Review of Law and Economics, $43-58$.

63. Cousy, H. (1997). Recent developments in environmental insurance. In: $F$. Abraham, R. Deketelaere and J. Stuyck (Eds), Recent Economic and Legal Developments in European Envirommental Policy, p 241; and Rogge, J. (1997). Les assurances en matiere d'emwhomement, Loose-Leaf, Kluwer, 39.

64. See Wagner, G. (1991). Umwelthaftung und Versicherung, Versicherungsrecht, 249-260; and Wagner, G. (1992). Die Zukunft der Umwelthaftpflichtversicherung, Versicherumgsrecht, $261-272$.

65. This point is also made in the Green Paper, 13. See also Rogge, J. (1997). Les assurances en matiere d'environnement, Loose-Leaf, Kluwer, 40.

66. So Monti, A. (2001). Environmental risk: A comparative law and economics approach to liability and insurance, European Review of Prwate Law, 65.

67. See Rogge, J. (1997). Les assurances en marière d'environnement, Loose-Leaf, Kluwer; 38.

68. See Bocken, $H_{\text {, }}$ and Ryckebost. D. (Eds) (1996). Codification of Environmental Law, Draft decree on Environmental Policy, London. Kluwer Law International, 106.

69. Bocken, H., Ryckbost, D., and Deloddere, S. (1996). Liability and financial guarantees. In: H. Bocken and D. Ryckbost (Eds), Codification of environmental law, Draft Decree on Environmental Policy, London, Kluwer Law International, 214-223.

70. See Council Directive $96 / 61 / \mathrm{EC}$ of 24 September 1996 concerning Integrated Pollution Prevention and Control, Official Joumal, 10 October 1996, L 257/26.

71. So Bocken, H. Rechtstreekse verzekeringen ten behoeve van derden en andere wisseloplossingen voor aansprakelijkbeid en aansprakelijkheidsverzekering. Een typologie. In: Liber Amicorum René van Gompel, 35.

72. See the report of the Commission to the European Parliament and to the Council of 12 May 1999 concerning the operation of the exemption regulation 3932/92. (com (1999) 92 final).

73. Official joumal, L $398 / 7$ of 31 December 1992.

74. For this criticism see Fanre, M. and Van den Bergh, R., "Restrictions of competition on insurance markets and the applicability of EC antitrust law", Kyklos, vol. 48, $1995,65-85$.

75. And was criticised among others by Fame, M., and Harthief, T. (1998). Een schadefonds als allenarief voor aansprakelijkheid en verzekering, $R M$ Themis, 220-222.

76. See report, no. 18 , p. 9 . 
77. See Faure, M., and Hartief, T. (1996). Ontwikkelingen in de werkgeversaansprakelijkheid voor beroepsziekten: aanleiding voor een nieuwe AVB-polis?, A\&V, 140-151. For a critical comment see Haazen, O. A., and Spier, J. (1996). Amerikaanse toestanden en de nieuwe aansprakelijkheidsverzekering voor bedrijven en beroepen, NJB, $45-50$.

78. See Spier, J., and Haazen, O. A. (1996). Aansprakelikheidsverzekeringen op claims-made grondslag, Deventer, Kluwer; and Wansink, J. H. (1996). Het polismodel AVB '96 en de dekking voor long-tail risico's, $A \& V, 120-122$.

79. See also Haazen, O. A., and Spier, J. (1996). Amerikaanse toestanden en de nieuwe aansprakelijkheidsverzekering voor bedrijven en beroepen. Nederlands JuristenBlad, 45.

80. See Faure, M., and Van den Bergh, R. (2000). Aansprakelijkheidsverzekering, concurrentie en ongevallenpreventie. In: T. Hartlief and M. Mendel (red.), Verzekering en maatschappij, Deventer, Kluwer, 315-342.

\section{REFERENCES}

Abraham, K. (1988). Environmental Liability and the Limits of Insurance. Colwmbia Law Review, 88.

Akerlof, G. (1970). The market for "lemons": quality, uncertainty and the market mechanism. Quarterly Journal of Economics, 488-500.

Akkermans, A. (1997). Proportionele aansprakelijkheid bij onzeker causad! werband. Deventer. Tjeenk Willink.

Arrow, K. (1965). Aspects of the Theory of Risk-Bearing. Helsinki, Yrjö Jahnssonin Suatiö.

Bergkamp, L. (1999). De wernuler betaalt dubbel. Antwerpen, Intersentia.

Bocken, H., Ryckbost, D., \& Deloddere, S. (1996). Liability and financial guarantees. In: H. Bocken \& D. Ryckbost (Eds), Cadification of Environmental Law. Drafi Decree on Environnental Policy (pp. 214-223). London: Kluwer Law International.

Bohrenstein, S. (1989). The Economics of Costly Risk Sorting in Competitive Insurance Markets. Intemational Review of Law and Economics, 25-39.

Borch, K. (1961). The Utility Concept Applied to the Theory of Insurance. The Astin Bulletin, $245-255$.

Borch, K. (1963). Recent Developments in Economic Theory and their Application to Insurance. The Astin Bulletin, 322-341.

CEA. (1998). Study on first party legal obligations for clean-ups and comesponding insurance covers in European Countries. Paris: CEA, 21 October.

Council Directive 96/61/EC of 24 September 1996 concening Integrated Pollution Prevention and Control. Official Jawnal, 10 October 1996, L 257/26.

Cousy, H. Recent developments in environmental insurance. In: F. Abratham, K. Deketelacre \& I. Stuyck (Eds). Recent economic and legal developments in European emironmental policy. 240.

Cowell, I. Compulsory environmental liability insurance. In: H. Bocken \& D. Ryckbost (Eds), Insurance of Environmental Damage (p. 327).

Danzon, P. (1999). Alternative liability regimes for medical injuries. Geneva Papers on Risk and Irsurance. 3-22.

Drion, P. J. M. (1998). Milieu onder én dak: milieuschadeverzekering (MSV). Verzekeringsrechtelijke Berichten, 2, 19-21. 
Ehrlich, 1., Posner, R. (1974). An Economic Analysis of Legal Rule-Making. Journal of Legal Studies, 257.

Fatre, M. \& Van den Bergh. R. (1995). Restrictions of competition on insurance markets and the applicability of EC antitrust law. Kyklos, 48, 65-85.

Faure. M. Hartlief, $\Upsilon$. (1996). Ontwikkelingen in de werkgeversaansprakelijkheid voor beroepsziekten: aanleiding woor cen nieuwe AVB-polis? A\&V, 140-151.

Faure, M., \& Hartlief, Tr. (1998). Remedies for expanding liability. Oxford Journal of Legal Studie, $18,681-706$.

Faure, M., \&artief, T. (1998). Een schadefonds als alternatief voor atansprakelijkheid en verzekering, RM Themis, $220-222$.

Fature, M., \& Fenn, P. (1999). Retroactive liability and the insurability of long tail risks, Intemational Regiew of Law and Economics, 487-500.

Faure. M." Grimeatud, D. (2000). Financial assurance issues of environmental liability "funal version 4.12,2000.

Faure, M., \& Van den Bergh, R. (2000). Aansprakelijkheidswerzekering, concurrentic en ongevallenpreventie. In: T. Hartlief M. Mendel (Eds), Verzekering en maatschappij (pp. 315-342). Dewenter: Kluwer.

Frenk, N. (1995). Toerekening naar kansbepaling. Nederland's Juristemblad, 482-491.

Haazen, O. A., \& Spier, J. (1996). Amerikatanse toestanden en de nieuwe aansprakelijkheidswerzekering voor bedrijwen en beroepen. Nederlands JuristenBlad, 45.

Janssen, C. A. (1998). Aansprakelijkheid voor milieuschade en financiële zekerheid natar toekomstig recht: nieuwe oplossingen. Nederlands Recht. In: L. F. Wiggers-Rust \& $\mathrm{K}$. en Deketelaere, (Eds), Aansprakelijkneid woor milieuschade en financiële zekerheid (pp. 111-112). Die Keure - Vermande.

Jost, P. J. (1996). Limited liability and the requirement to purchase insurance. International Review of Law and Economics, 259-276.

Katzman, M. (1988). Pollution liability insurance and catastrophic enviromental risk. Joumal of Risk and Insurance, 89-90.

Koziol, (1997). Die Arzthaftung im geltenden und kunftigen Recht, Hafungsrechthiche Perspektuvew der Arztichen Behandlung, Linx, Universitätswerlag Rudolf Trauner, 2I-35.

Kunteuther, H., Hogarth, R., \& Meszaros, I. (1993). Insurer Ambiguity and Market Failure. Jounol of Risk and Uncertainty, $7 !-87$.

Monti. A. (2001). Environmental risk: A comparative law and economics approach to liability and insurance. Elaropean Review of Private Law, 51-79.

Niezen, J. (1998). Nieuwe milienschardeverzekering - geen panacee, Milien en Recht, 114. Official journat. L $398 / 7$ of 31 December 1992.

Ogus, A. I. (1981). Quuntitative Rules and Judicial Decision-Making. In: Burrows \& Veljanowski (Eds), The Economic Approach to Law (pp. 210-225). London: Butterworth.

Oguss A. I. (1994). Standard Setting for Enrirommental Protection: Principles and Processes. In: M. Faure, J. Verwaele \& A. Weale (Eds), Enwironnental Standards in the European Union (pp. 25-37).

Pauly. M. (1968). The Economics of Moral Hazard: Comment. American Economic Review, $531-545$.

Polborn, M. (1998). Mandatory Insurance and the Ihdgement-Proof Problem. International Review of Law and Economics, 141-146.

Posner, R. (1998). Economic Analysis of Law (5th ed.). New York: Aspen Law \& Business.

Pratt, J. (1964). Risk Awersion in the Small and in the Large. Econometrica, 122-136.

Priest, G. (1987). The current insurance crisis and modern tort law. Yale Law Joumal, 1521-1590. 
Radetzki. M. (2000). Private arrangements to cover large-scale liability caused by muclear and other industrial catastrophes. The Geneva Papers on Risk and Insurance, $180-195$.

Ranson, D. (2000). Verzekering van milieuaansprakelijkheid. Witien-en Energierechn, 68 .

Rehbinder, E. (2000). Towards a community environmental liability regime: the commissions white paper on environmental liability. Exworwnental Lability, 85-96.

Rice. P. (2000). From Lugano to Brussels via Aarhus: enwironmental liability white paper pulblished. Emironmental Liability. $39-45$.

Richardson, B. J. (2000). Financial Institutions for Sustainability. Envirommental Liability, 61.

Robinson. G. (1985). Probabilistic catisation and compensation for tortious risk. Jound of Legal Situdies, 798 .

Rogge, J. (1997). Les assurances en matiere d"enwironmement. Loose-lLeaf, KIuwer.

Rosenberg. D. (1984). The causal connection in Mass Exposure cases: a 'public law' vision of the tort system. Harvard Law Review, 851-929.

Shavell. S. (1979). On Moral Hazard and Insurance. Quavterly Joumal of Economics, 541-562.

Shavell, S. (1985). Uncertainty over causation and the determination of civil liability. Journal of Law and Economics, 587-609.

Shavell, S. (1986). The judgement proof problem. International Review of Law and Economics, $43-58$.

Shavell, S. (1987). Economic analysis of accident Jaw. Cambridge: Harvard University Press, 190.

Skogh, G. (1989). The transactions cost theory of insurance: contracting impediments and costs. Joumal of Risk and Insurance, 726-732.

Skogh, G. (2000). Mandatory Insurance: Transaction Costs Analysis of Insurance. In: B. Bouckaert \& G. De Geest (Eds), Encyclopedia of Law and Economics. Chelfemham: Edward Elgar, $521-537$

Spence, M., Zeckhauser, R. (1971). Insurance, Information, and Individual Action, American Economic Review, 380-39l.

Spier, J. (1990). Sluipende schade, Deventer: KI hwer.

Spier, I. (Ed.) (1996). The limits of liability, keeping the floodgates shut. The Hague: Kluwer.

Spier, J., \& Hazzen, O. A. (1996). Aansprakelijkheidsverzekeringen op ciatns-made grondsiag* Deventer, Kluwer.

Spier, J. De widijende reikwijhte van het aansprakelijkheidsrecht. prewadvies Nederlandse Juristenvereniging.

The report of the Commission to the European Parliament and to the Council of 12 May 1999 concerning the operation of the exemption regulation $3932 / 92$ (com (1999) 92 final).

Tyran, J. R , \& Zweifel P. (1993). Environmental risk internalization through capital markets (Ericam): the case of nuclear power. International Review of Law and Economics, $431-444$.

van Eijk-Graveland, I. C. (1998). Verzekerbadheid wan opzet in het schadeverzekeringstech. Zwolle: Tjeenk Willink.

Viscusi, W. K. (1991). The Dimensions of the Product Liability Crisis. Joumal of Legal Stadies, $147-177$.

Wagner, G. (1991). Unwelthaftung und Versicherung. Versicherungstechi, 249-260.

Wagner, G. (1992). Die Zukunfi der Umwelthaftphlichtversicherung. Versicherungsrecht, 261-272.

Wagner, G. (1996). Versicherungsfragen der Umwelthattung. In: M. Ahrens be J. Smon (Eds), Umwelthaftung, Risikostemerung and Versichenung (pp. 104-105). Berlin: Erich Schmidt Verlag.

Wansink, J. H. (1985). De nieuwe milieuaansprakelijkheidsverzekering. Milieu en Rech, 98.

Wansink. J. H. (1996). Het polismodel AVB 96 en de dekking voor long-tail risico's. AdV, $120-122$ 
Wansink, J. H. (1997). Hoe plotseling en onzeker is de verzekeringsdekking voor millieuaransprakelijkheidsrisico's? In: Miscellamea. Juris Consuhto vero dedicara (pp. 451-460). Essays offered to Prof. Mr. J. M. van Dunné. Deventer: Kluwer.

Wansink. J. H. (1999). Verzekering en milieuschade als gevolg wan werwer/opslag van gevaarlike stoffien. Tijdschrift voor Milieuaansprakelijkheid, 77-82.

Wils, W. P. J. (1994). Insurance Risk Classifications in the EC: Regulatory Outlook. Oxford Joumal of Legral Studies, 449467.

Zeckhauser, R. (1996). 19th Annual Lecture of the Genewa Association and Catastrophes. The Geneva Papers on Risk and Insurance, 5. 


\title{
COMMENTS ON PAPER BY MICHAEL FAURE
}

\author{
James Boyd
}

My comments are limited to a small set of areas that I think deserve some further clarification.

First, I think that it is imperative to make clear the important difference between mandatory and voluntary insurance. If cost internalization (compensation) and deterrence are the policy goal, it is most natural to think of insurance - normatively - as being mandatory. Voluntary insurance, if cost internalization is the goal, cannot be counted on to get the job done. (Voluntary insurance being geared toward utility improvements in the presence of risk aversion, when risks are borne by the insuring party themselves.) The firms most at risk of externalizing costs will also be the firms least likely to voluntarily self-insure, since the costs of insurance will be highest for them. (I think Michael is familiar with my views on this subject. And to be clear, I am not angling for a reference to my views. I do think, however, that a clearer contrast or acknowledgment of the differences in motivation for mandatory ws. voluntary insurance should be provided up front in the paper).

Second, I found the distinction between first-party insurance and "direct insurance" to be somewhat muddy - early in the paper. Also, the paper's real focus is on the "direct" mechanism so that should be the focus of the introduction.

Third, in the discussion of the Dutch approach, and the "direct approach" generally, it is unclear what the real benefit of this system is to the insured. From the U.S. perspective, it is hard to see how eliminating the protection of liability standards would be an improvement. An improvement arises for them

An Introduction to the Law and Economics of Environmental Policy: Issues in Institutional Design, Volume 20, paiges 329-33n.

(c) 2002 Published by Elsevier Science Ltd.

ISAN: 0-7623-0888-5 